\title{
Differential expression of innate and adaptive immune genes in the survivors of three gibel carp gynogenetic clones after herpesvirus challenge
}

Wei-Jia Lu ${ }^{1,2}$, Fan-Xiang Gao ${ }^{1,2,3}$, Yang Wang ${ }^{1,2}$, Qi-Ya Zhang ${ }^{1,2}$, Zhi Li ${ }^{1}$, Xiao-Juan Zhang ${ }^{1}$, Li Zhou ${ }^{1,2^{*}}$ and Jian-Fang Gui ${ }^{1,2^{*}}$ (D)

\begin{abstract}
Background: Accompanied with rapid growth and high density aquaculture, gibel carp has been seriously threatened by Carassius auratus herpesvirus ( $\mathrm{CaHV}$ ) since 2012. In previous study, distinct $\mathrm{CaHV}$ resistances and immune responses were revealed in the diseased individuals of three gibel carp gynogenetic clones $\left(A^{+}, F\right.$ and $\left.H\right)$. However, little is known about the gene expression changes in the survivors after $\mathrm{CaHV}$ challenge, particularly their differences of innate and adaptive immune system between susceptible clone and resistant clone.

Results: We firstly confirmed the CaHV carrier state in the survivors of three gibel carp clones after CaHV challenge by evaluating the abundances of five $\mathrm{CaHV}$ genes. The assay of viral loads indicated the resistant clone $\mathrm{H}$ possessed not only stronger resistance but also higher tolerance to $\mathrm{CaHV}$. Then, 2818, 4047 and 3323 differentially expressed unigenes (DEUs) were screened from the head-kidney transcriptome profiles of survivors compared with controls from clone $\mathrm{A}^{+}$, $\mathrm{F}$ and $\mathrm{H}$. GO and KEGG analysis suggested that a persistent immune response might sustain in resistant clone $\mathrm{H}$ and $\mathrm{F}$, while susceptible clone $\mathrm{A}^{+}$had a long-term impact on the circulatory system which was consistent with the major symptoms of bleeding caused by $\mathrm{CaHV}$. Among the top 30 enriched pathways of specifically up-regulated DEUs in respective clones, 26, 7 and 15 pathways in clone $\mathrm{H}, \mathrm{F}$ and $\mathrm{A}^{+}$were associated with infections, diseases, or immunerelated pathways respectively. In addition, 20 pathways in clone F belonged to "metabolism" or "biogenesis", and 7 pathways involved in "circulatory system" were enriched in clone A $^{+}$. Significantly, we revealed the differential expression changes of IFN system genes and immunoglobulin (lg) genes among the survivors of three clones. Finally, myosins and Igs were identified as co-expression modules which were positively or negatively correlated to CaHV viral loads respectively.
\end{abstract}

Conclusions: Our results revealed the common and distinct gene expression changes in immune and circulatory system in the survivors of three gibel carp gynogenetic clones with different $\mathrm{CaHV}$ resistances. The current study represents a paradigm of differential innate and adaptive immune reactions in teleost, and will be beneficial to the disease-resistance breeding of gibel carp.

Keywords: Gibel carp, Herpesvirus, Transcriptome, Survivors, IFN, Immunoglobulin, Myosin

\footnotetext{
* Correspondence: zhouli@ihb.ac.cn; jfgui@ihb.ac.cn

${ }^{1}$ State Key Laboratory of Freshwater Ecology and Biotechnology, Institute of Hydrobiology, The Innovation Academy of Seed Design, Chinese Academy of Sciences, Wuhan 430072, Hubei, China

Full list of author information is available at the end of the article
}

(c) The Author(s). 2019 Open Access This article is distributed under the terms of the Creative Commons Attribution 4.0 International License (http://creativecommons.org/licenses/by/4.0/), which permits unrestricted use, distribution, and reproduction in any medium, provided you give appropriate credit to the original author(s) and the source, provide a link to the Creative Commons license, and indicate if changes were made. The Creative Commons Public Domain Dedication waiver (http://creativecommons.org/publicdomain/zero/1.0/) applies to the data made available in this article, unless otherwise stated. 


\section{Background}

Gibel carp (C. gibelio), as a natural polyploid fish [1, 2], widely distributes across the Eurasian continent [3-9] and is able to reproduce by unisexual gynogenesis or sexual reproduction [10-16]. Recently, we discriminated numerous various gynogenetic clones of gibel carp from 35 locations through mainland China by transferrin allele and mtDNA haplotype polymorphism [5, 6]. Along with the large-scale application of several improved varieties, all-female allogynogenetic gibel carp activated by heterologous sperm has become one of the most important farmed fish in China [17]. The annual production capacity has increased to more than 2.82 million tons in 2017 [18]. However, the highly intensive farming has resulted in serious disease problems. Especially, the infections of herpesvirus $\mathrm{CaHV}$ in crucian carp (Carassius auratus), a newly emerged epizootic disease with acute gill hemorrhages and high mortality, has outbroken in main culture areas of Jiangsu province and caused huge economic losses since 2012 [19].

Herpesviruses are widespread among vertebrates, some of which caused devastating diseases in aquaculture [20-25]. One of effective ways to reduce the threat is to breed resistant strains or crossbreeds to viral infection [26]. In our previous study, we revealed the distinct resistances to herpesvirus $\mathrm{CaHV}$ among three gynogenetic clones of gibel carp through herpesvirus $\mathrm{CaHV}$ challenge experiments. Allogynogenetic gibel carp "CAS III" (clone $\mathrm{A}^{+}$) [27], the most popularly cultured variety in China, was a highly susceptible clone. The novel variety (clone F) [28], nominated as the allogynogenetic gibel carp "CAS V", showed moderately resistant to $\mathrm{CaHV}$. We also identified a wild clone $\mathrm{H}$ as a strongly resistant clone [29]. Our results confirmed that the ability of fish to resist infection was strongly influenced by genetic factors [30-34].

The first step towards disease-resistance breeding is the search for associations between disease resistance and molecular markers. Teleost possesses complicated innate immune network and primitive adaptive immune system [35-37]. When the pathogen invaded, the innate immune system provides the immediate sensing and elimination of pathogens in a nonspecific and nonmemory manner, while the adaptive immune system offers delayed and highly specialized responses with immunologic memory features [38, 39]. Through transcriptome analysis among control and diseased individuals from clone $\mathrm{A}^{+}, \mathrm{F}$ and $\mathrm{H}$, we revealed that resistant clone $\mathrm{H}$ of gibel carp activated stronger innate interferon (IFN)-mediated antiviral response, while susceptible clone $\mathrm{A}^{+}$lost the battle with $\mathrm{CaHV}$ and evidently induced apoptosis or death [29]. Eight IFN system genes, exhibiting sharply up-regulated and higher expression in resistant clone $\mathrm{H}$ than those in susceptible clone $\mathrm{A}^{+}$and $\mathrm{F}$ at 1 or 3 days post infection (dpi), were identified as candidate resistant-related genes [40]. However, little is known about the gene expression changes in the survivors after $\mathrm{CaHV}$ challenge, particularly their differences of innate and adaptive immune system responses between susceptible clone and resistant clone. In this study, we first confirmed the carrier state in survivors of three gibel carp clones after $\mathrm{CaHV}$ challenge. Then, we revealed the common and distinct gene expression changes in immune and circulatory system in the survivors of gibel carp three clones by comprehensive transcriptomic analysis and qPCR. Finally, we performed weighted gene correlation network analysis (WGCNA) to identify the co-expression modules correlated to resistant traits.

\section{Results \\ Confirmation of herpesvirus $\mathrm{CaHV}$ carrier state in gibel carp survivors after $\mathrm{CaHV}$ challenge}

The three gynogenetic gibel carp clones $\left(\mathrm{A}^{+}, \mathrm{F}\right.$ and $\left.\mathrm{H}\right)$ exhibited significantly different resistance to $\mathrm{CaHV}$ [29]. The mortalities caused by $\mathrm{CaHV}$ began at $3 \mathrm{dpi}$ and subsided after $14 \mathrm{dpi}$, resulting in cumulative mortalities of $98.89,86.67$ and $51.11 \%$ in clone $\mathrm{A}+, \mathrm{F}$ and $\mathrm{H}$. The survivors appeared healthy at $28 \mathrm{dpi}$. We first tested the abundances of five $\mathrm{CaHV}$ genes, including helicase-primase helicase subunit (hel), capsid triplex subunit 2 (cap), uracil-DNA glycosylase (ung), deoxyuridine triphosphatase (dut), and thymidylate kinase (tmk) in the control individuals, diseased individuals and survivors to evaluate the $\mathrm{CaHV}$ carrier state (Fig. 1a). After 40 amplification cycles, no DNA fragment was amplified from the control individuals (c), while strong or weak bands were amplified in the diseased individuals with sub-clinical symptoms (d) or survivors (s) respectively.

Then, the viral loads were evaluated by real-time PCR (Fig. 1b). The control individuals from three clones were confirmed to be $\mathrm{CaHV}$-free. A few of $\mathrm{CaHV}$ particles were detected with loads of $10^{1.27 \pm 0.31}, 10^{0.73 \pm 0.07}$, and $10^{0.70 \pm 0.16}$ particles/ng DNA in survivors from clone $\mathrm{A}^{+}$, $\mathrm{F}$ and $\mathrm{H}$ respectively, implying that survivors had conquered the herpesvirus and eventually survived with $\mathrm{CaHV}$ carrier state. Extremely abundant $\mathrm{CaHV}$ particles were detected in the diseased individuals. Different from lower viral loads in resistant clone $\mathrm{H}$ than that in susceptible clone $\mathrm{A}^{+}$during the early infected stage (1-5 dpi) $[29,40]$, higher viral loads were detected in the diseased individuals of clone $\mathrm{H}\left(10^{6.29 \pm 0.14}\right)$ than that in the diseased individuals of clone $\mathrm{A}^{+}\left(10^{5.61 \pm 0.02}\right)$ (Fig. 1b). These results further confirmed that the resistant clone $\mathrm{H}$ possessed not only stronger resistance but also higher tolerance to $\mathrm{CaHV}$. 


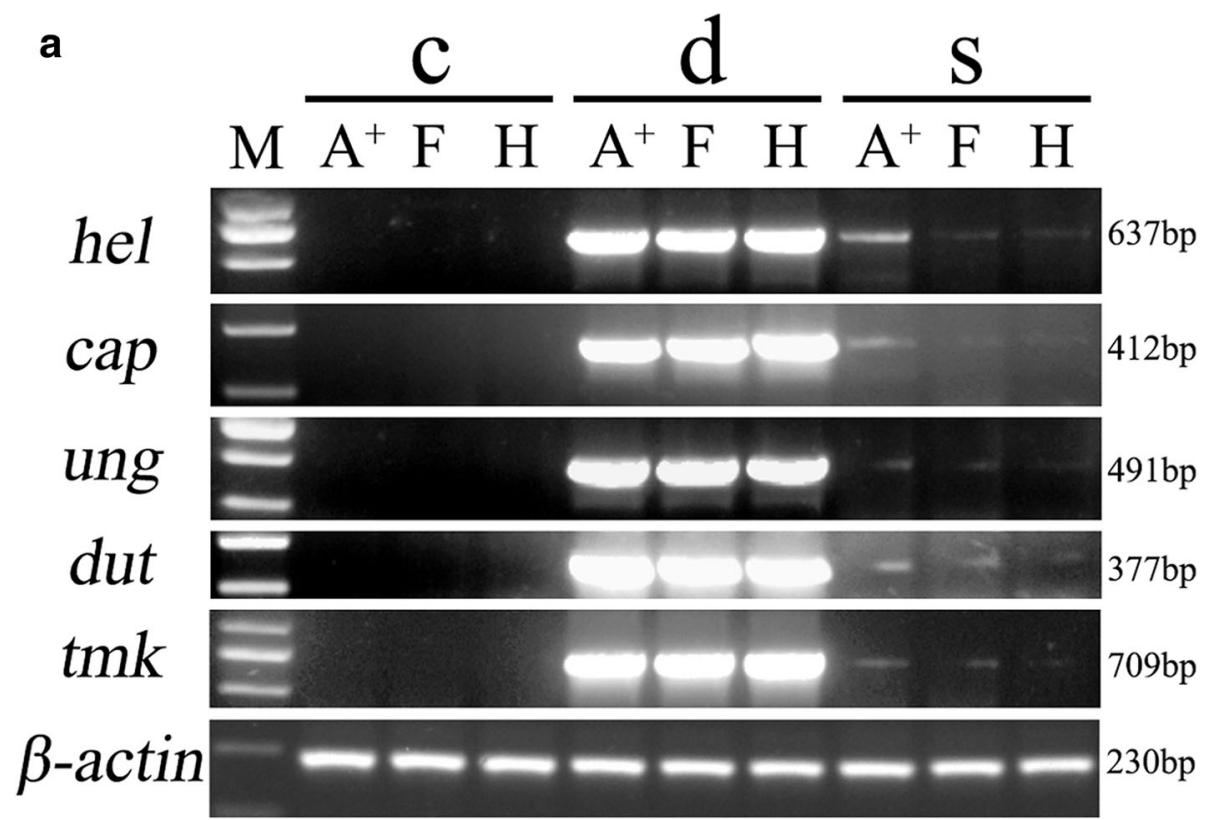

b

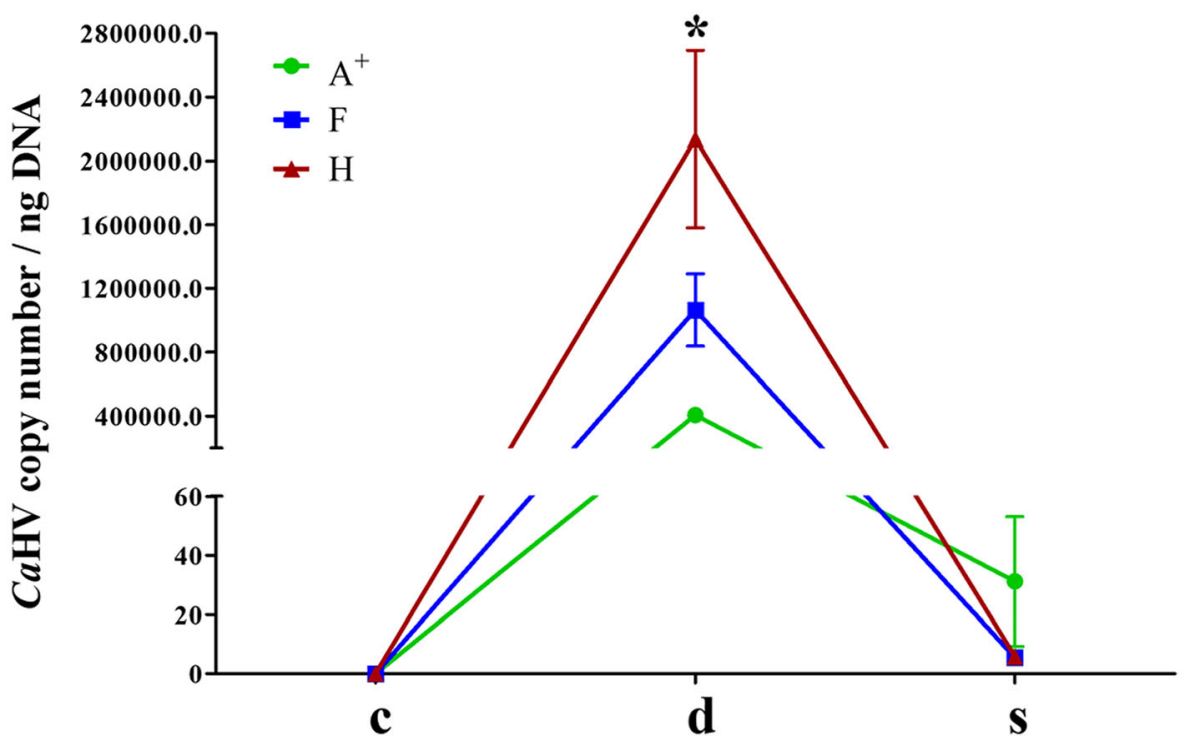

Fig. $1 \mathrm{CaHV}$ detection and quantification in the control individuals (c), diseased individuals with sub-clinical symptoms (d) or survivors (s) from three gynogenetic gibel carp clones $\left(\mathrm{A}^{+}, \mathrm{F}\right.$ and $\mathrm{H}$ ). a Electrophoretogram of the PCR amplified products of five CaHV genes (hel, cap, ung, dut and $t m k)$. $\beta$-actin was selected as reference gene. Gene symbols and the sizes of amplified products are indicated by the left and right side of the figure, respectively. b CaHV viral loads. Data are shown as means \pm standard deviation (SD) $(n=3)$ representing CaHV copy number per ng DNA. The asterisk indicates the significant difference between resistant clone and susceptible clone $(p<0.05)$

Stronger immune responses persisted in survivors of gibel carp resistant clone after CaHV challenge

In our previous study, we analyzed the comparative transcriptome data between control and diseased individuals [29]. To better understand the interactive mechanisms between gibel carp and $\mathrm{CaHV}$, we further identified 2818, 4047 and 3323 differentially expressed unigenes (DEUs) (probability $\geq 0.8$ and relative change $\geq 2$ ) from the head-kidney transcriptome profiles of survivors (s) compared with control individuals (c) from clone $\mathrm{A}^{+}, \mathrm{F}$ and $\mathrm{H}\left(\mathrm{s}-\mathrm{A}^{+}\right.$vs $\mathrm{c}-\mathrm{A}^{+}, \mathrm{s}-\mathrm{F}$ vs $\mathrm{c}-\mathrm{F}$, and $\mathrm{s}-\mathrm{H}$ vs $\mathrm{c}-\mathrm{H}$ ) respectively (Additional file 1 : Table S1, Additional file 2 Table S2 and Additional file 3: Figure S1). 
GO (Gene Ontology) analysis showed that the DEUs identified from s- $\mathrm{A}^{+}$vs c- $\mathrm{A}^{+}$, s-F vs c-F and $\mathrm{s}-\mathrm{H}$ vs c- $\mathrm{H}$ were categorized into 51, 51 and 47 terms with similar distribution patterns, respectively. Nevertheless, subtle differences of categories were found among three clones (Fig. 2). For cellular component, the percentages of DEUs in term "extracellular matrix" and "membrane-enclosed lumen" identified from resistant clone $\mathrm{H}$ were significant higher than those identified from susceptible clone $\mathrm{A}^{+}$, while remarkably less DEUs of clone $\mathrm{H}$ were distributed in the "cell junction" and "macromolecular complex" compared with clone $\mathrm{A}^{+}$. For molecular function, the rates of term "antioxidant activity", "nucleic acid binding transcription factor activity", "electron carrier activity", and "transporter activity" exhibited noticeable differences between s- $\mathrm{A}^{+}$vs c- $\mathrm{A}^{+}$and s- $\mathrm{H}$ vs c-H.

KEGG (Kyoto Encyclopedia of Genes and Genomes) pathway mapping revealed that 4,9 and 8 pathways enriched in $\mathrm{s}^{-\mathrm{A}^{+}}$vs c- $\mathrm{A}^{+}$, s-F vs c-F and s- $\mathrm{H}$ vs $\mathrm{c}-\mathrm{H}$ were associated with "immune system", "immune diseases", "infectious diseases", and "cardiovascular diseases" among the top 10 enriched pathways (Additional file 4: Figure S2; Additional file 5: Table S3). 570, 873, and 602 DEUs were categorized into "organismal systems". The percentages of DEUs mapped into pathway "immune system" in resistant clone $\mathrm{H}(34.1 \%)$ and clone F (31.2\%) was significantly higher than that in susceptible clone $\mathrm{A}^{+}$ (27.0\%), while less ratios of DEUs mapped into pathway "circulatory system" in clone $\mathrm{H}(3.7 \%)$ and clone $\mathrm{F}$ (6.5\%) were observed when compared to that in susceptible clone $\mathrm{A}^{+}$(9.1\%) (Fig. 3a-c). The results indicate that stronger immune responses persisted in the survivors of gibel carp resistant clone $\mathrm{H}$ after $\mathrm{CaHV}$ challenge. In addition, the results also imply the obvious pathological changes in circulatory system occurred in susceptible clone $\mathrm{A}^{+}$, consistent with the main symptom of breeding in gibel carp after $\mathrm{CaHV}$ challenge.

\section{Activation of circulatory and immune system in the survivors of all three gibel carp clones}

Through integrating the shared DEUs among s- $\mathrm{A}^{+}$vs c- $\mathrm{A}^{+}$, s-F vs c-F and s-H vs c-H, only 113 and 1 DEUs were up-regulated or down-regulated in all three clones obtained from the total of 5613 up-regulated DEUs and 3889 down-regulated DEUs (Fig. 4a; Additional file 6: Table S4). Among 113 commonly up-regulated DEUs, 49 DEUs are annotated as genes which are the membrane proteins of erythrocyte (ank1 and $s p t b)$ or participate in heme biosynthesis and metabolism (alas2, hmbs, urod, cpox, fech, and blvrb), oxygen and ion transport (hba, hbb, tfr, mfrn1, slc4a1, and cahz), or proliferation and differentiation of blood cells (hemge,

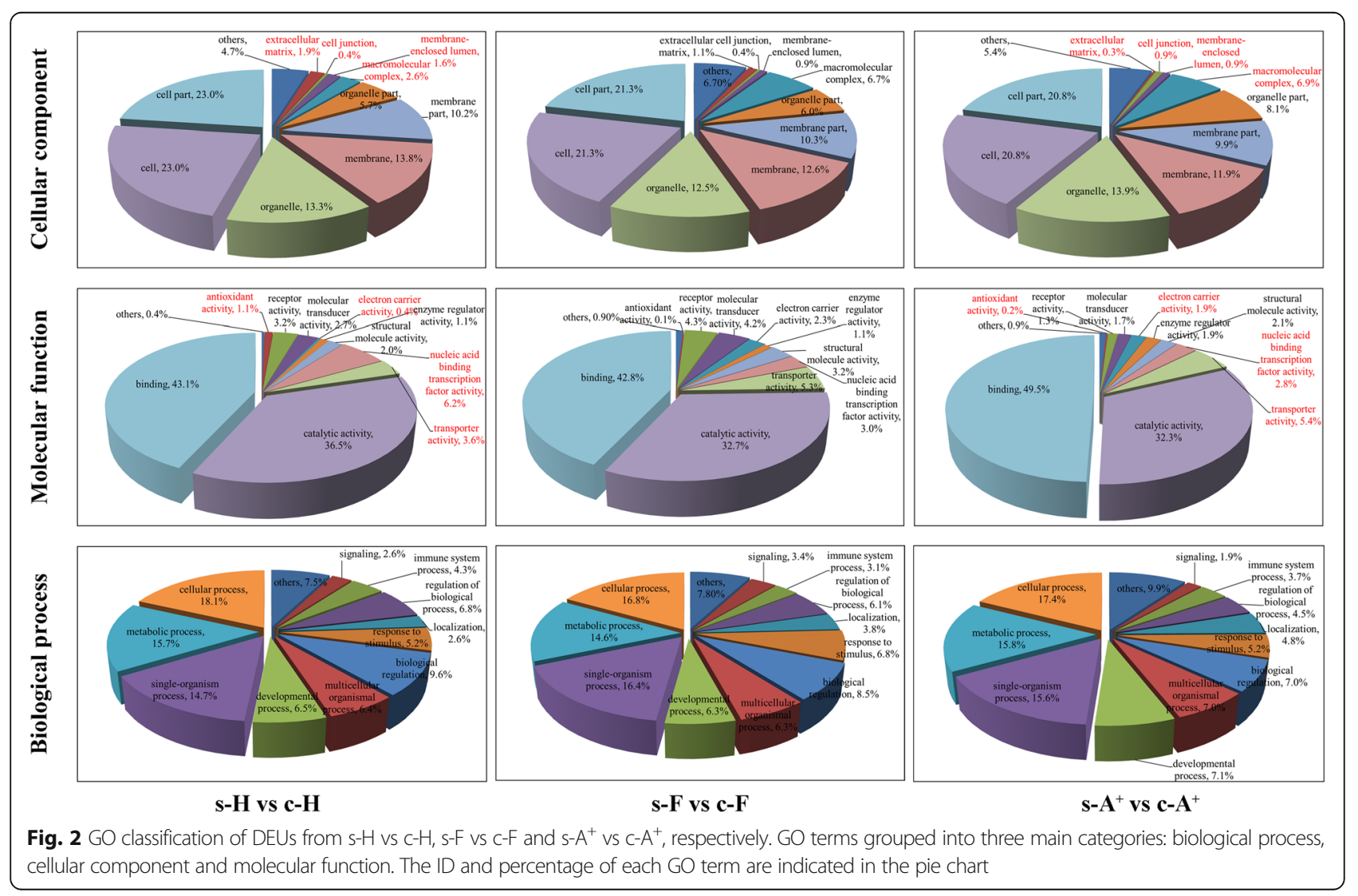




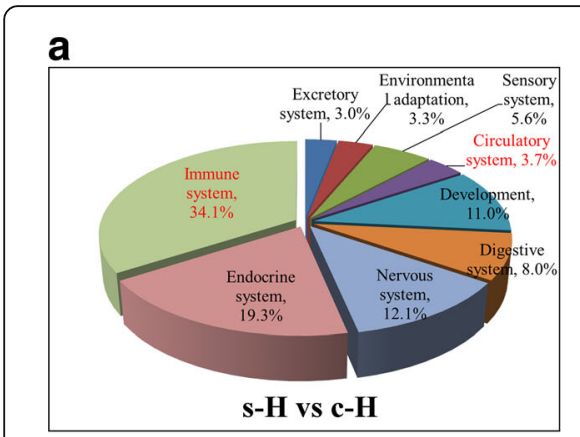

d

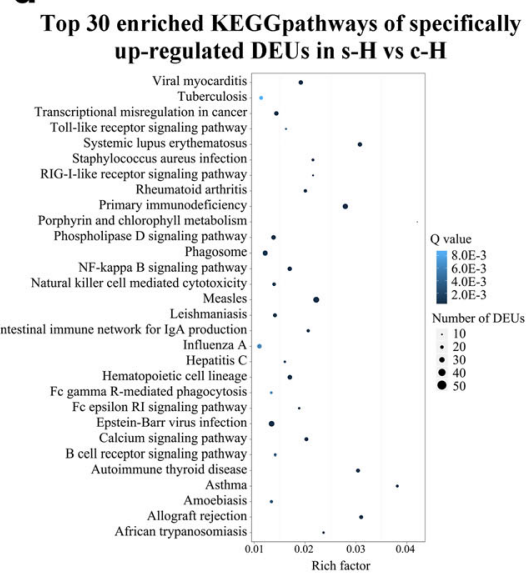

g

Top 30 en riched KEGGpathways of specifically

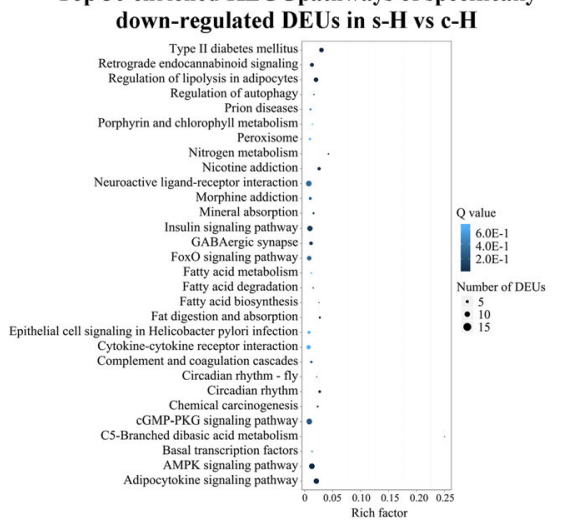

b

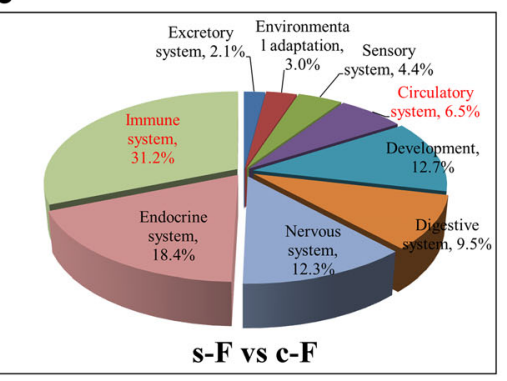

e

Top 30 enriched KEGGpathways of specifically up-regulated DEUs in s-F vs c-F

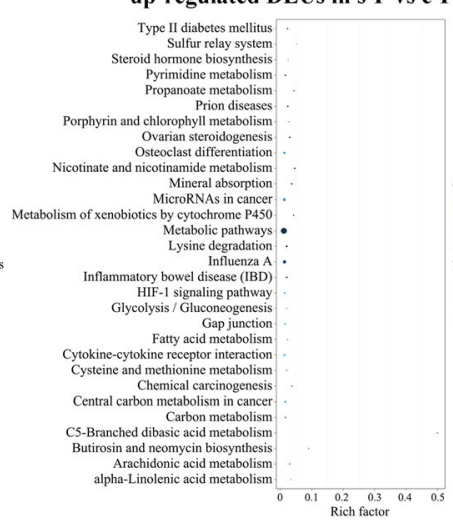

h

Top 30 enriched KEGGpathways of specifically
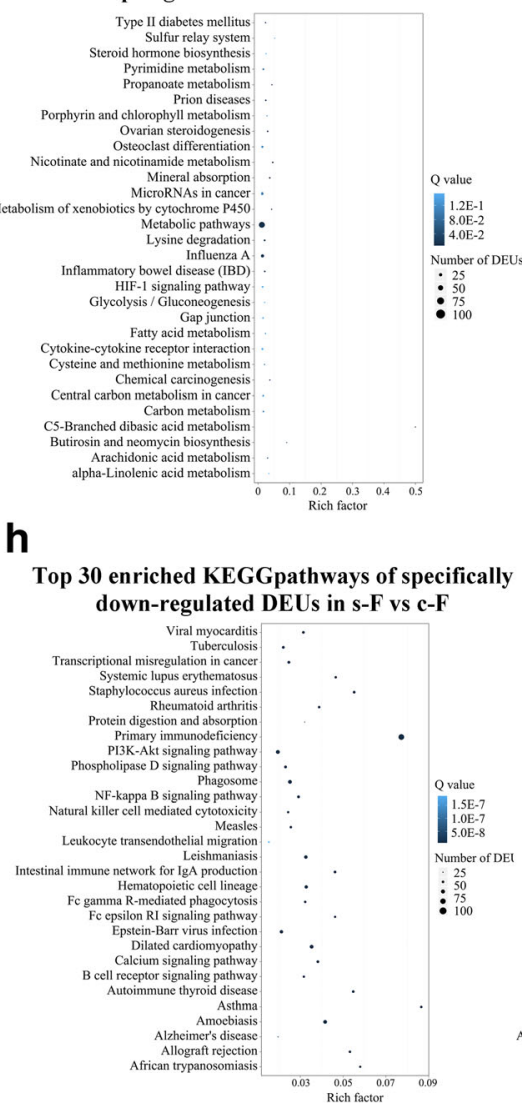

C

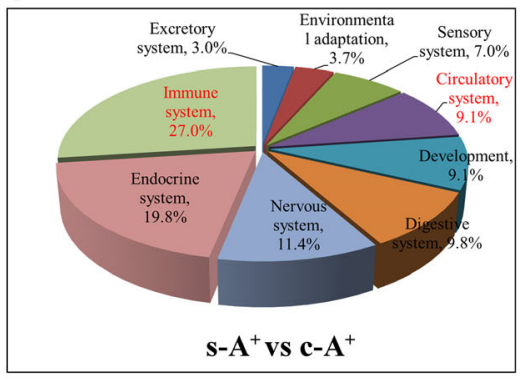

f

Top 30 enriched KEGGpathways of specifically up-regulated DEUs in s- $\mathrm{A}^{+}$vs $\mathbf{c - A ^ { + }}$

\section{i}

Top 30 enriched KEGGpathways of specifically

down-regulated DEUs in $\mathbf{s - \mathrm { A } ^ { + }}$ vs c-A $\mathrm{A}^{+}$

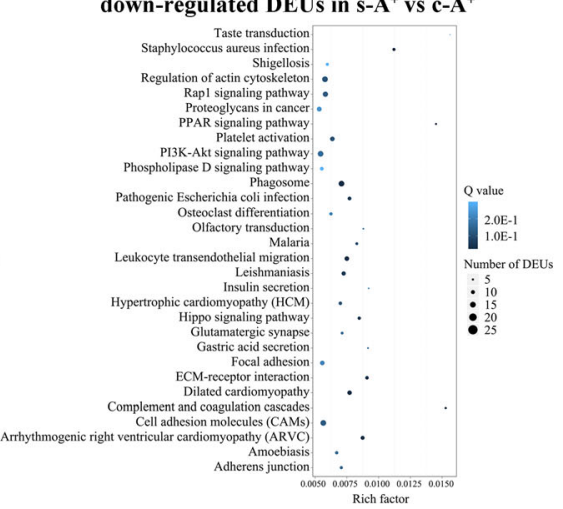

Fig. 3 KEGG pathway enrichment analysis. a-c Functional classification of DEUs in KEGG term "organismal systems" from s-H vs c-H (a), s-F vs c-F (b) and $\mathrm{s}-\mathrm{A}^{+}$vs c- $\mathrm{A}^{+}$(c). The ID and percentage of each KEGG term are indicated in the pie chart. d-i Top 30 enriched KEGG pathways of specifically up- or down-regulated DEUs from s-H vs c-H, s-F vs c-F and s- $\mathrm{A}^{+}$vs c- $\mathrm{A}^{+}$, respectively. The $\mathrm{x}$-axis indicates the rich factor of each pathway and $y$-axis shows pathway. The color and size of dot indicates $\mathrm{Q}$ value and the number of DEUs assigned to the corresponding pathway respectively

klf1 and fam210b) (Table 1). We selected 8 genes, including sptb, urod, cpox, fech, blvrb, hba, mfrn1, and fam $210 b$, and confirmed their commonly up-regulated expression in the survivors of all three gibel carp clones in comparison with control individuals by qPCR (Fig. 4b).

Moreover, 21 DEUs were mapped to innate immunity (gig2, ifi44, pla2g4b, and alox15) or adaptive immunity (klf13, stab1, spen, mycbp2, huwe1, nf1, birc6, klf17, and $p i k k s$ ), and the last six genes were involved in cell proliferation and tissue repair (Table 2). These results indicate that $\mathrm{CaHV}$ infection results in the activation of circulatory or immune system in the survivors of all three gibel carp clones. In addition, we also identified 10 highly up-regulated DEUs which were involved in vesicle transport or cycling, such as vacuolar protein sorting-associated protein 13C (vps13c), sodium/bile acid cotransporter 4 (slc10a4) and WD repeat and FYVE domain-containing 
a

Up-regulation
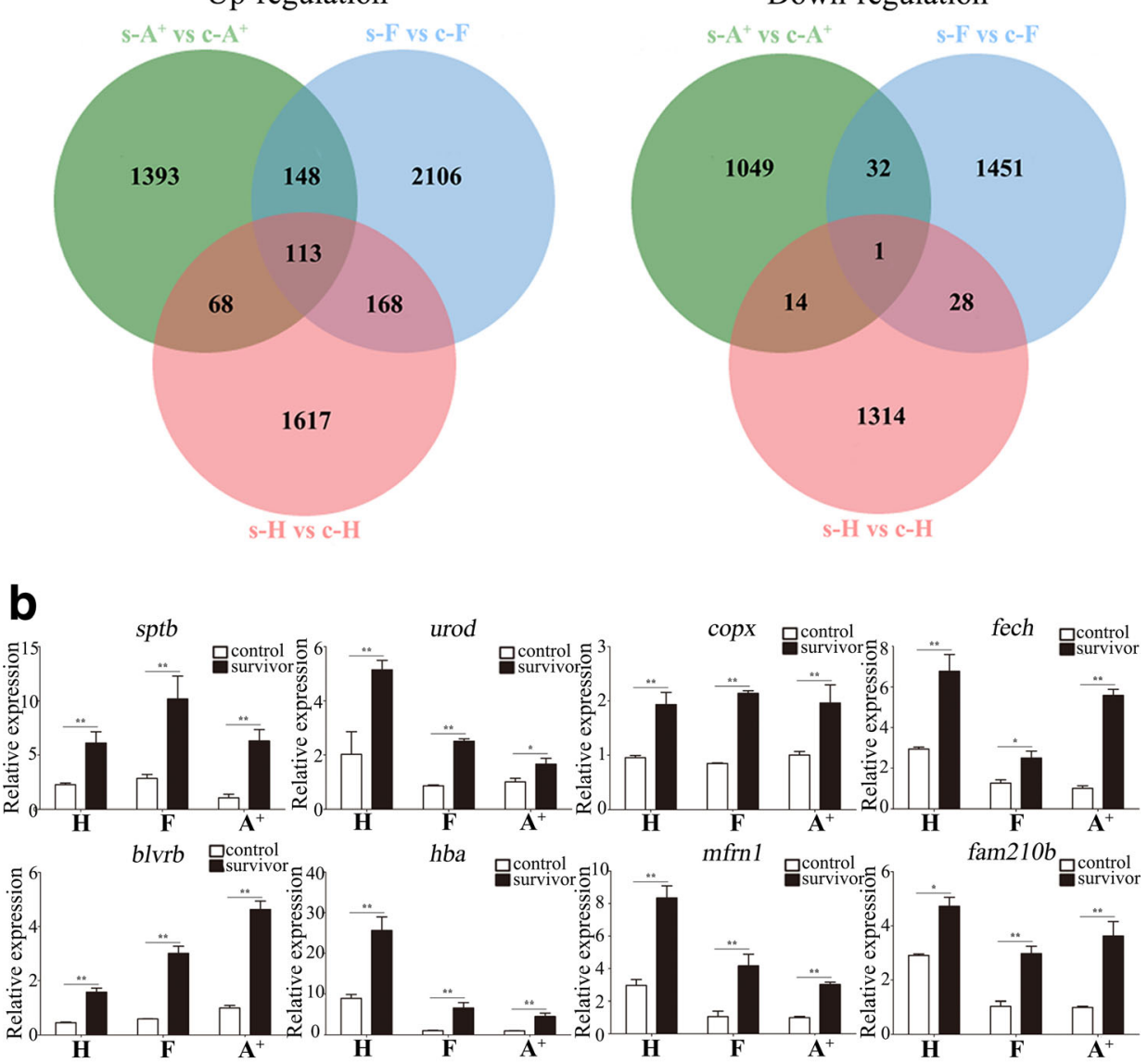

14

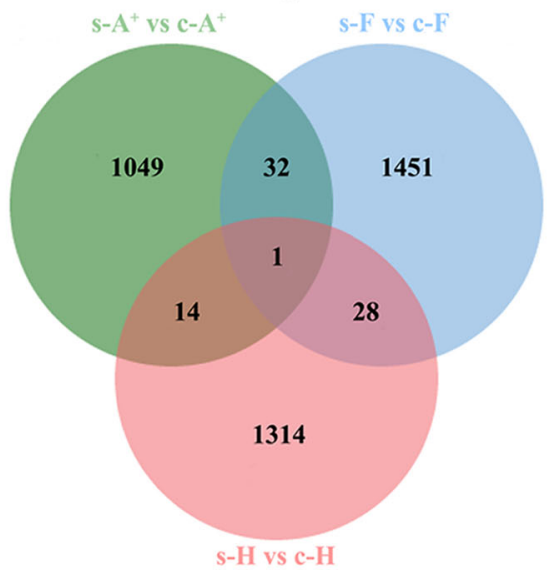

Down-regulation

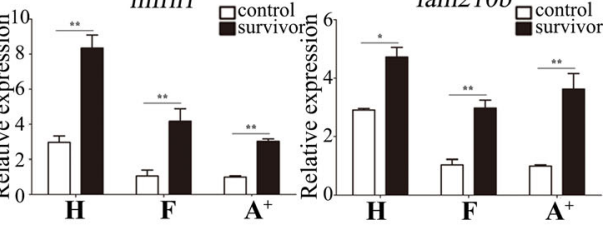

C s-H vs c-H s-F vs c-F s- $\mathrm{A}^{+}$vs c- $\mathrm{A}^{+}$

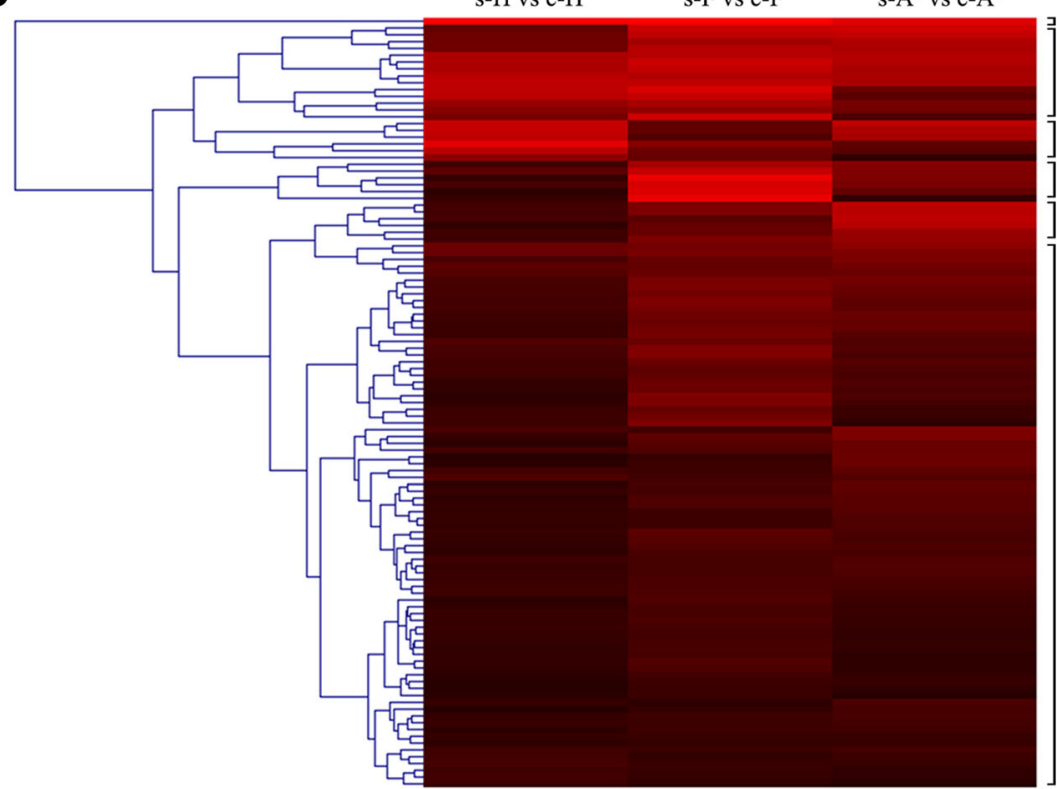

Cluster 3

Cluster 4

Cluster 5

Cluster 6

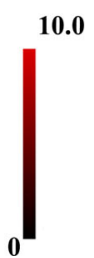

Fig. 4 (See legend on next page.) 
(See figure on previous page.)

Fig. 4 Commonly up-regulated DEUs from s-H vs c-H, s-F vs c-F and s-A $A^{+}$vs $c-A^{+}$. a Venn diagram of up- or down-regulated DEUs from s-A $A^{+}$vs c- $\mathrm{A}^{+}$(green circle), s-F vs c-F (blue circle) and s-H vs c-H (red circle). b The qPCR analyses of eight genes (sptb, urod, cpox, fech, blvrb, hba, mfrn 1 and fam210b) related to circulatory system in head kidney of gibel carp clone $\mathrm{A}^{+}, \mathrm{F}$ and H. eefla1/1 was used as the normalizer. Gene expression levels are relative to that of clone $\mathrm{A}^{+}$control individuals. Each bar represents mean \pm standard deviation (SD) $(n=3)$. Asterisks indicate the significant differences between control and survivor (*: $p<0.05$ and ${ }^{* *}: p<0.05$ ). $\mathbf{c}$ Heatmap of commonly up-regulated DEUs among s-H vs c-H, s-F vs c-F and s$\mathrm{A}^{+}$vs $c-\mathrm{A}^{+}$. Hierarchical clustering is calculated by $\log _{2}$ fold change values and the main clusters were lined out on the right

protein 4 (wdfy4). Only one DEU (CL16220.Contig1_All) exhibited commonly down-regulated among three gibel carp clones and was annotated as metallothionein (mt1).

Hierarchical clustering analysis showed that the commonly up-regulated DEUs were classified into six clusters (Fig. 4c). The cluster 1 contained only one DEU (CL11903.Contig1_All) which was not annotated in any of the public databases and displayed remarkably up-regulated (about $2^{10}$ folds) expression in the survivors of all three gibel carp clones compared to control individuals, while the cluster 6 included about two-thirds of DEUs which exhibited moderately and similarly up-regulated expression in the survivors of all three gibel carp clones. The cluster 3 and 5 represented the distinct responses to $\mathrm{CaHV}$ between resistant clone $\mathrm{H}$ and susceptible clone $\mathrm{A}^{+}$. DEUs in cluster 3 showed higher increase levels in $\mathrm{s}-\mathrm{H}$ vs $\mathrm{c}-\mathrm{H}$ than those in $\mathrm{s}-\mathrm{A}^{+}$ vs $\mathrm{c}^{-} \mathrm{A}^{+}$, and most of them involved in immune reaction, such as mycbp, birc6, klf13 and ifi44. On the contrary, DEUs in cluster 5 displayed relatively higher upregulation in $\mathrm{s}^{-} \mathrm{A}^{+}$vs $\mathrm{c}-\mathrm{A}^{+}$than those in $\mathrm{s}-\mathrm{H}$ vs $\mathrm{c}-\mathrm{H}$, and half of them, including sptb and $h b b$, were related to the blood circulation system. In addition, the cluster 2 and 4 contained spen, gig2, huwe1, klf13 and pikks, which exhibited the most remarkable upregulation in clone $\mathrm{F}$. The above results indicated that a persistent immune response might sustain in resistant clone $\mathrm{H}$ and $\mathrm{F}$, while susceptible clone $\mathrm{A}^{+}$had a long-term impact on the circulatory system.

\section{Distinct signaling pathways among the survivors of three gibel carp clones}

In total, 1393, 2106 and 1617 DEUs were specifically up-regulated their expression levels in the survivors of clone $\mathrm{A}^{+}, \mathrm{F}$ and $\mathrm{H}$, respectively in comparison with the control individuals (Fig. 4a; Additional file 6: Table S4).

Table 1 Category of commonly up-regulated DEUs annotated in the circulatory system from s-H vs c- $\mathrm{H}$, s- $\mathrm{F}$ vs c- $\mathrm{F}$ and s- $\mathrm{A}^{+}$vs c- $\mathrm{A}^{+}$

\begin{tabular}{|c|c|c|c|}
\hline Gene Name & $\begin{array}{l}\text { Gene } \\
\text { Abbrev-iation }\end{array}$ & Function annotation & Unigene ID \\
\hline Delta-aminolevulinate synthase & alas2 & \multirow{6}{*}{$\begin{array}{l}\text { Heme biosynthesis and } \\
\text { metabolism }\end{array}$} & CL55.Contig1, CL55.Contig2, CL55.Contig3 \\
\hline Ferrochelatase & fech & & CL8987.Contig5, CL8987.Contig6, Unigene35721 \\
\hline $\begin{array}{l}\text { Hydroxymethylbilane } \\
\text { synthase } b\end{array}$ & hmbsb & & $\begin{array}{l}\text { CL8862.Contig4, CL8862.Contig1, CL8862.Contig7, CL8862.Contig6, } \\
\text { CL8862.Contig3, CL8862.Contig2 }\end{array}$ \\
\hline Uroporphyrinogen decarboxylase & urod & & CL158.Contig2, CL158.Contig1, CL158.Contig3 \\
\hline $\begin{array}{l}\text { Coproporphyrinogen } \\
\text { oxidase }\end{array}$ & cpox & & CL3455.Contig8 \\
\hline Flavin reductase & blvrb & & CL8222.Contig4, CL8222.Contig2, CL8222.Contig5 \\
\hline Hemoglobin alpha & $h b a$ & \multirow[t]{6}{*}{ Oxygen and ion transport } & CL5869.Contig1, CL5869.Contig2, CL5869.Contig6 \\
\hline Hemoglobin beta & $h b b$ & & Unigene31300, Unigene86068, Unigene6944, Unigene22310, \\
\hline Transferrin receptor & $t f r$ & & $\begin{array}{l}\text { CL14300.Contig2, CL14300.Contig4, CL14300.Contig5, } \\
\text { Unigene38629, CL14300.Contig1 }\end{array}$ \\
\hline Mitoferrin-1 & mfrn1 & & CL45.Contig4, CL45.Contig1 \\
\hline Band 3 anion transport protein & slc4al & & CL6154.Contig1, CL6154.Contig4, CL6154.Contig3 \\
\hline Carbonic anhydrase & cahz & & Unigene28427 \\
\hline Hemogen & hemge & \multirow[t]{3}{*}{$\begin{array}{l}\text { Proliferation and differentiation } \\
\text { of haemocytes }\end{array}$} & $\begin{array}{l}\text { CL5210.Contig1, CL5210.Contig4, CL5210.Contig2, CL5210.Contig5, } \\
\text { CL5210.Contig3 }\end{array}$ \\
\hline Kruppel-like factor 1 & klfi & & CL4920.Contig3, CL4920.Contig1 \\
\hline $\begin{array}{l}\text { Family with sequence similarity } \\
210 \text { member B }\end{array}$ & fam $210 b$ & & CL6436.Contig3, \\
\hline Ankyrin 1 & ank1 & \multirow[t]{2}{*}{ Erythrocyte membrane structure } & Unigene12266 \\
\hline Spectrin beta & sptb & & Unigene1305, CL16738.Contig5 \\
\hline
\end{tabular}


Table 2 Category of commonly up-regulated DEUs annotated in the immune system from s-H vs c- $\mathrm{H}$, s- $\mathrm{F}$ vs c- $\mathrm{F}$ and s- $\mathrm{A}^{+}$vs c- $\mathrm{A}^{+}$

\begin{tabular}{llll}
\hline Gene Name & Gene Abbrev-iation & Category & Unigene ID \\
\hline grass carp hemorrhagic virus-induced gene 2 & gig2 & Innate immunity & CL5938.Contig2, CL5938.Contig1 \\
interferon-induced protein 44 & ifi44 & & Unigene19789 \\
cytosolic phospholipase A2 beta & pla2g4b & CL1686.Contig3, CL1686.Contig18, CL1686.Contig14 \\
arachidonate 15-lipoxygenase & alox15 & & CL1331.Contig11, CL1331.Contig10 \\
krueppel-like factor 13 & klf13 & Adaptive immunity & Unigene33364, Unigene73086 \\
stabilin-1 & Stab1 & & CL3993.Contig1 \\
msx2-interacting protein & spen & CL16106.Contig2 \\
E3 ubiquitin-protein ligase mycbp2 & mycbp2 & & Unigene17417, Unigene38807, \\
E3 ubiquitin-protein ligase huwe1 & huwe1 & CL4981.Contig5, CL4981.Contig1 \\
nuclear factor 1 & nf1 & CL14567.Contig1 \\
baculoviral IAP repeat-containing protein 6 & birc6 & & CL14135.Contig1 \\
kruppel-like factor 17 & klf17 & CL10390.Contig2 \\
phosphatidylinositol 3-kinase-related kinase & pikks & Unigene23119 \\
\hline
\end{tabular}

KEGG pathway analysis mapped these DEUs into 245, 276 and 252 pathways respectively (Additional file 7: Table S5). Among the top 30 enriched pathways, 26 pathways in resistant clone $\mathrm{H}$ were associated with infections, diseases, or immune-related pathways, such as "NF-kappa B signaling pathway", "intestinal immune network for IgA production", "Fc epsilon RI signaling pathway", "RIG-I-like receptor signaling pathway", and "toll-like receptor signaling pathway" (Fig. 3d). However, two-thirds of the top 30 pathways in s-F vs c-F belonged to "metabolism" or "biogenesis", and only 7 pathways were involved in diseases or immune (Fig. 3e). In susceptible clone $\mathrm{A}^{+}, 7$ pathways involved in "cardiovascular diseases" or "circulatory system" were enriched among the top 30 pathways. In addition, 15 pathways were related to the infection, diseases, or immune (Fig. 3f).

Similarly, a total of 1049, 1451 and 1314 DEUs were identified as specifically down-regulated DEUs of clone $\mathrm{A}^{+}, \mathrm{F}$ and $\mathrm{H}$, and mapped to 233, 249 and 243 pathways respectively (Additional file 6: Table S4 and Additional file 7: Table S5). Among the top 30 enriched pathways, we found 11 pathways related to "metabolism" in resistant clone $\mathrm{H}, 25$ pathways involved in infections, diseases or immune in clone $\mathrm{F}$, and 5 pathways associated with "circulatory system" or diseases in clone $\mathrm{A}^{+}$(Fig. 3g-i). The differential top 30 pathways of specifically up-regulated or down-regulated DEUs in $\mathrm{s}-\mathrm{A}^{+}$vs c- $\mathrm{A}^{+}, \mathrm{s}-\mathrm{F}$ vs c-F and $\mathrm{s}-\mathrm{H}$ vs $\mathrm{c}-\mathrm{H}$ revealed distinct immune responses activated or sustained in the survivors of three gibel carp clones.

\section{Differential expressions of IFN system genes and immunoglobulin genes among the survivors of three gibel carp clones}

Among these DEUs specific to $\mathrm{s}-\mathrm{H}$ vs $\mathrm{c}-\mathrm{H}, 58$ specifically up-regulated DEUs were annotated as IFN system genes, including host pattern recognition receptors (lgp2, tlr4b, tlr22, nlrp3 and nlrp12), PRR-mediated IFN signal pathway (stat1 and stat2), IFN regulatory factors (irf7), interferon-induced proteins or IFN antiviral effectors $(m x 1, m x 3$, viperin, ifi27, ifi44, ifi56, gig1, gig2, gvinp1, and irgc) (Table 3; Additional file 8: Table S6). We also found 43 specifically up-regulated DEUs belonged to immunoglobulin (Ig) superfamily, such as Ig light chain ( $I g L \lambda$ and $\operatorname{Ig} L \kappa)$, Ig heavy chain $(\operatorname{Ig} M, \operatorname{IgD}$ and $\operatorname{IgZ}$ ), and polymeric Ig receptor-like (pIgRL) (Table 3; Additional file 8: Table S6). The results suggest that both innate immune system and adaptive immune system persisted in activating in the survivors of resistant clone $\mathrm{H}$ after $\mathrm{CaHV}$ challenge.

Similarly, 50 specifically up-regulated DEUs identified from $\mathrm{s}-\mathrm{F}$ vs c-F were classified into IFN system genes, such as ifn $\gamma 1$, ifn $\gamma r 2$, ifitm, $g b p, m x 1, m x 3$ and so on (Table 3; Additional file 8: Table S6). Interestingly, the dynamic expression patterns of Ig genes in moderate resistant clone $\mathrm{F}$ were completely different from the high resistant clone $\mathrm{H}$. A total of 118 specifically down-regulated DEUs were annotated as members of Ig superfamily, including $\operatorname{Ig} L \lambda$ (66), $\operatorname{Ig} L \kappa(1), \operatorname{Ig} M$ (40), and IgZ (11). The above results indicate that IFN immune system still retained high expression levels, while the adaptive immune system might be impaired in the survivors of clone $\mathrm{F}$.

In comparison with control individuals, the expression changes of IFN system genes and Ig genes in the survivors of susceptible clone $\mathrm{A}^{+}$exhibited distinct pattern from those in the resistant clone $\mathrm{H}$ and $\mathrm{F}$. Ten specifically up-regulated and 14 specifically down-regulated DEUs were annotated as IFN system genes, including lgp2, nlrc3, irf3, irf7, isg15, $m \times 1, m x 3$, or viperin (Table 3; Additional file 8: Table S6). We also identified 33 and 
Table 3 Number of specifically up/down-regulated DEUs annotated as IFN system genes, immunoglobulins or myosins from s-H vs $\mathrm{C}-\mathrm{H}$, s-F vs C-F and s-A $\mathrm{A}^{+}$vs C-A

\begin{tabular}{|c|c|c|c|c|c|c|c|c|}
\hline \multirow[t]{2}{*}{ Category } & & \multirow[t]{2}{*}{$\begin{array}{l}\text { Gene } \\
\text { Abbrev-iation }\end{array}$} & \multicolumn{3}{|c|}{ Number of up-regulated DEUs } & \multicolumn{3}{|c|}{$\begin{array}{l}\text { Number of down-regulated } \\
\text { DEUs }\end{array}$} \\
\hline & & & $\begin{array}{l}\mathrm{s}-\mathrm{H} \text { vs C- } \\
\mathrm{H}\end{array}$ & $\begin{array}{l}s-F \text { vs C- } \\
F\end{array}$ & $\begin{array}{l}S_{-}-A^{+} \text {VS C- } \\
A^{+}\end{array}$ & $\begin{array}{l}\mathrm{S}-\mathrm{H} \text { vS C- } \\
\mathrm{H}\end{array}$ & $\begin{array}{l}\text { s-F vs C- } \\
\text { F }\end{array}$ & $\begin{array}{l}S_{-} A^{+} \text {Vs C- } \\
A^{+}\end{array}$ \\
\hline \multirow[t]{29}{*}{ IFN system } & \multirow[t]{7}{*}{ host pattern recognition receptors } & lgp2 & 3 & 1 & 0 & 0 & 0 & 1 \\
\hline & & tr $4 b$ & 1 & 0 & 0 & 0 & 0 & 0 \\
\hline & & $\operatorname{tr} r 22$ & 2 & 0 & 0 & 0 & 0 & 0 \\
\hline & & $\operatorname{tr} 7 a$ & 0 & 0 & 0 & 0 & 1 & 0 \\
\hline & & nlrp3 & 4 & 7 & 3 & 4 & 1 & 3 \\
\hline & & nlrp12 & 4 & 4 & 1 & 0 & 0 & 0 \\
\hline & & ifnyr2 & 0 & 3 & 0 & 0 & 0 & 0 \\
\hline & \multirow[t]{2}{*}{ PRR-mediated IFN signal pathway } & stat1 & 3 & 3 & 0 & 0 & 0 & 0 \\
\hline & & stat2 & 3 & 0 & 0 & 0 & 0 & 0 \\
\hline & \multirow[t]{2}{*}{ IFN regulatory factor } & irf3 & 0 & 0 & 0 & 0 & 0 & 1 \\
\hline & & irf7 & 4 & 0 & 0 & 0 & 0 & 1 \\
\hline & \multirow{17}{*}{$\begin{array}{l}\text { interferon- induced proteins or IFN antiviral } \\
\text { 7effectors }\end{array}$} & $m \times 1$ & 4 & 6 & 4 & 3 & 3 & 3 \\
\hline & & $m \times 3$ & 2 & 3 & 0 & 0 & 0 & 1 \\
\hline & & viperin & 4 & 0 & 0 & 0 & 0 & 2 \\
\hline & & ifi27 & 2 & 0 & 0 & 0 & 0 & 0 \\
\hline & & ifi44 & 4 & 6 & 0 & 0 & 0 & 1 \\
\hline & & ifi56 & 1 & 0 & 0 & 0 & 0 & 0 \\
\hline & & gigl & 4 & 1 & 0 & 0 & 0 & 0 \\
\hline & & gig2 & 3 & 0 & 0 & 0 & 0 & 0 \\
\hline & & gvinpl & 4 & 9 & 1 & 0 & 0 & 0 \\
\hline & & irgc & 2 & 0 & 0 & 0 & 0 & 0 \\
\hline & & isg15 & 3 & 0 & 0 & 0 & 0 & 1 \\
\hline & & eif2ak2 & 1 & 0 & 0 & 0 & 0 & 0 \\
\hline & & $g b p$ & 0 & 2 & 0 & 0 & 0 & 0 \\
\hline & & traf2 & 0 & 1 & 0 & 0 & 0 & 0 \\
\hline & & $t 2 b p$ & 0 & 1 & 0 & 0 & 0 & 0 \\
\hline & & ifitm 1 & 0 & 1 & 0 & 1 & 0 & 0 \\
\hline & & Ifitm3 & 0 & 1 & 0 & 0 & 0 & 0 \\
\hline & \multirow[t]{2}{*}{ interferon } & ifny 1 & 0 & 1 & 1 & 0 & 0 & 0 \\
\hline Total number & & & 58 & 50 & 10 & 8 & 5 & 14 \\
\hline \multirow[t]{7}{*}{ Immunoglobulin } & \multirow[t]{3}{*}{ immunoglobulin heavy chain } & $\lg M$ & 15 & 0 & 7 & 0 & 40 & 3 \\
\hline & & $\lg Z$ & 3 & 0 & 5 & 0 & 11 & 3 \\
\hline & & $\lg D$ & 1 & 0 & 1 & 0 & 0 & 0 \\
\hline & \multirow[t]{2}{*}{ immunoglobulin light chain } & $\lg L \lambda$ & 13 & 0 & 19 & 4 & 66 & 4 \\
\hline & & $\lg L K$ & 10 & 0 & 0 & 0 & 1 & 1 \\
\hline & immunoglobulin receptor-like & plgRL & 1 & 1 & 1 & 0 & 0 & 0 \\
\hline & \multirow[t]{2}{*}{ immunoglobulin superfamily } & lgsf3 & 0 & 0 & 0 & 1 & 0 & 2 \\
\hline Total number & & & 43 & 1 & 33 & 5 & 118 & 13 \\
\hline \multirow{3}{*}{$\begin{array}{l}\text { myosin } \\
\text { superfamily }\end{array}$} & \multirow[t]{3}{*}{ myosin heavy chain } & myh7 & 0 & 0 & 4 & 0 & 0 & 0 \\
\hline & & myh9 & 0 & 0 & 1 & 0 & 2 & 1 \\
\hline & & myh10 & 1 & 3 & 1 & 0 & 0 & 0 \\
\hline
\end{tabular}


Table 3 Number of specifically up/down-regulated DEUs annotated as IFN system genes, immunoglobulins or myosins from s-H vs $\mathrm{c}-\mathrm{H}, \mathrm{s}-\mathrm{F}$ vs $\mathrm{c}-\mathrm{F}$ and $\mathrm{s}-\mathrm{A}^{+}$vs $\mathrm{c}-\mathrm{A}^{+}$(Continued)

\begin{tabular}{|c|c|c|c|c|c|c|c|}
\hline \multirow[t]{2}{*}{ Category } & \multirow[t]{2}{*}{$\begin{array}{l}\text { Gene } \\
\text { Abbrev-iation }\end{array}$} & \multicolumn{3}{|c|}{ Number of up-regulated DEUs } & \multicolumn{3}{|c|}{$\begin{array}{l}\text { Number of down-regulated } \\
\text { DEUs }\end{array}$} \\
\hline & & $\begin{array}{l}\mathrm{s}-\mathrm{H} \text { vs } \mathrm{C}- \\
\mathrm{H}\end{array}$ & $\begin{array}{l}\text { s-F vs C- } \\
F\end{array}$ & $\begin{array}{l}{\mathrm{s}-\mathrm{A}^{+} \text {VS C- }}_{\mathrm{A}^{+}} \\
\end{array}$ & $\begin{array}{l}\mathrm{s}-\mathrm{H} \text { vs } \mathrm{C}^{-} \\
\mathrm{H}\end{array}$ & $\begin{array}{l}\text { s-F vs C- } \\
F\end{array}$ & $\begin{array}{l}{\mathrm{s}-\mathrm{A}^{+} \text {vs C- }}_{\mathrm{A}^{+}} \\
\end{array}$ \\
\hline & myh11 & 0 & 0 & 0 & 0 & 1 & 0 \\
\hline & myha & 0 & 0 & 2 & 0 & 0 & 0 \\
\hline & myhb & 0 & 0 & 1 & 0 & 2 & 0 \\
\hline & myo3b & 0 & 0 & 1 & 0 & 0 & 0 \\
\hline & myo5a & 0 & 0 & 0 & 1 & 0 & 0 \\
\hline & myo9b & 0 & 1 & 0 & 0 & 1 & 0 \\
\hline & myo10 & 0 & 1 & 0 & 0 & 1 & 0 \\
\hline & myo18a & 0 & 1 & 1 & 0 & 0 & 0 \\
\hline & myo18b & 0 & 0 & 0 & 1 & 0 & 0 \\
\hline \multirow[t]{5}{*}{ myosin light chain } & myll & 0 & 0 & 0 & 0 & 1 & 0 \\
\hline & myl2 & 0 & 0 & 2 & 0 & 2 & 0 \\
\hline & $m y / 3$ & 0 & 0 & 3 & 0 & 1 & 0 \\
\hline & myl10 & 0 & 0 & 1 & 0 & 1 & 0 \\
\hline & mylk & 2 & 0 & 0 & 1 & 0 & 0 \\
\hline Total number & & 3 & 6 & 17 & 3 & 12 & 1 \\
\hline
\end{tabular}

13 DEUs annotated as members of Ig superfamily which were specifically up-regulated or down-regulated their expression levels from $\mathrm{s}-\mathrm{A}^{+}$vs $\mathrm{c}-\mathrm{A}^{+}$. Moreover, a total of 17 specifically up-regulated DEUs belonged to myosin superfamily (myl2, myl3, myl10, myha, myhb, myh7, myh9, myh10, myo3b, and myo18a), which all mapped into the pathways of "circulatory system" or diseases in circulatory system (Fig. 3f).

To validate the differential expressions among the survivors of three gibel carp clones, 12 genes, including nine IFN system genes and three immunoglobulins, were selected for qPCR analysis (Fig. 5). Except ifi44 and ifi56, the other 7 IFN system genes were all down-regulated their expressions in the survivors of susceptible clone $\mathrm{A}^{+}$in comparison with control individuals, while the 9 genes were all up-regulated in the survivors of the resistant clone $\mathrm{H}$ and $\mathrm{F}$. Consistent with the transcriptome results, immunoglobulins ( $I g L \lambda, I g Z$ and $I g M)$ were down-regulated in s-F vs c-F, while up-regulated in $\mathrm{s}-\mathrm{H}$ vs $\mathrm{c}-\mathrm{H}$. In susceptible clone $\mathrm{A}^{+}$, the expression of $\operatorname{Ig} M$ was very low. Compared to control, IgM and $\operatorname{IgL\lambda }$ had little change of their expression, while $\operatorname{IgZ}$ were up-regulated in the survivors of clone $\mathrm{A}^{+}$. Significantly, most of these genes displayed relatively higher up-regulated folds in clone $\mathrm{H}$ than those in clone F. qPCR analysis confirmed the differential expressions of IFN system genes and immunoglobulins among the survivors of three gibel carp clones.

\section{Myosin and immunoglobulin identified as positively or negatively correlated genes to CaHV viral loads respectively}

Weighted gene correlation network analysis (WGCNA) was employed to further investigate the relationship between the expression changes of DEUs (Additional file 2: Table S2) and viral loads in the survivors of three gibel carp clones (Fig. 1). Based on the correlation coefficients of DEUs, 31 distinct co-expression modules were identified and labeled by randomly assigned colors (Fig. 6a). These modules were then correlated with resistance or susceptibility traits by calculating the correlations (Fig. 6b). The turquoise and lightsteelblue1 were the most significantly positively or negatively correlated with the viral loads in the survivors respectively (Fig. 6b; Additional file 9: Table S7). The turquoise module contained 146 DEUs, 12 of which were annotated as members of myosin superfamily (mylh2, mylh3, mylh10, myha, myh7, myo3b, and myo18a) (Additional file 9: Table S7). The lightsteelblue1 modules included only 35 DEUs, 11 of which belonged to $\operatorname{Ig}$ superfamily $(\operatorname{Ig} L \lambda, \operatorname{Ig} L \kappa$ and IgM) (Additional file 9: Table S7). The above results showed that myosin and immunoglobulin were positively or negatively correlated to $\mathrm{CaHV}$ viral loads respectively.

\section{Discussion}

Owing to its highly intensive farming, the culture industry of crucian carp has suffered enormous economic 


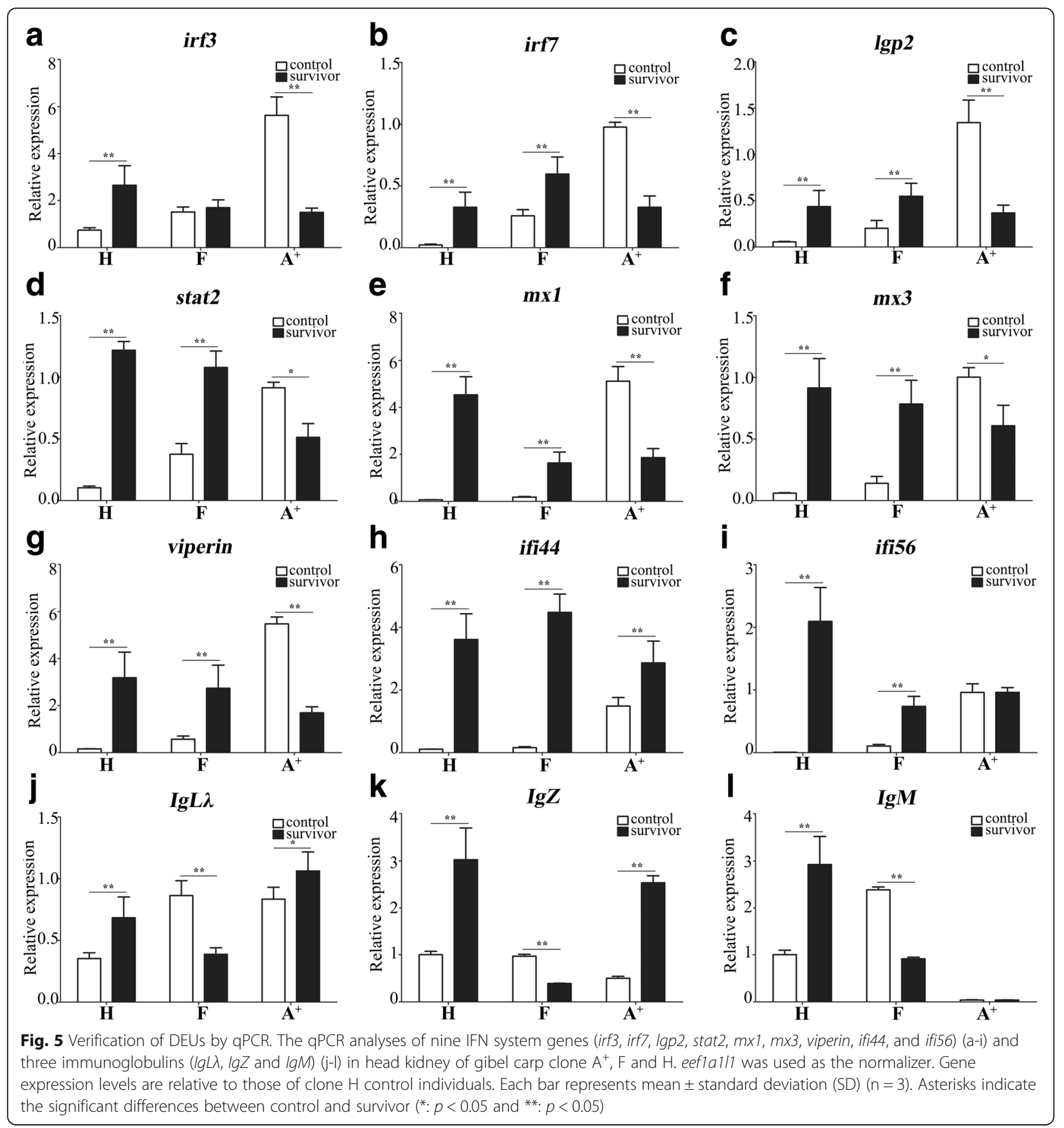

losses caused by $\mathrm{CaHV}$. In previous study, we screened the resistant clone $\mathrm{H}$ as the core breeding population and revealed the underlying antiviral mechanisms in gibel carp, activating IFN system and suppressing complements [29]. In this study, we confirmed that the resistant clone $\mathrm{H}$ possessed not only stronger resistance but also higher tolerance to $\mathrm{CaHV}$ (Fig. 1b). The GO and KEGG analysis showed that the genes related to circulatory and immune system were activated in the survivors of all three gibel carp clones after $\mathrm{CaHV}$ challenge
(Figs. 2 and 3 and Tables 1 and 2). Significantly, we revealed the distinct signaling pathways (Fig. 3) and differential gene changes of innate immune gene (IFN system genes) and adaptive immune system (Ig genes) among three gynogentic gibel carp clones (Fig. 5 and Table 3). Moreover, we identified myosins and Igs as positively or negatively correlated genes to $\mathrm{CaHV}$ viral loads by WGCNA respectively (Fig. 6).

Virus invasion induces a chain of immune responses in host. In fish, IFN response plays a vital role in the first 


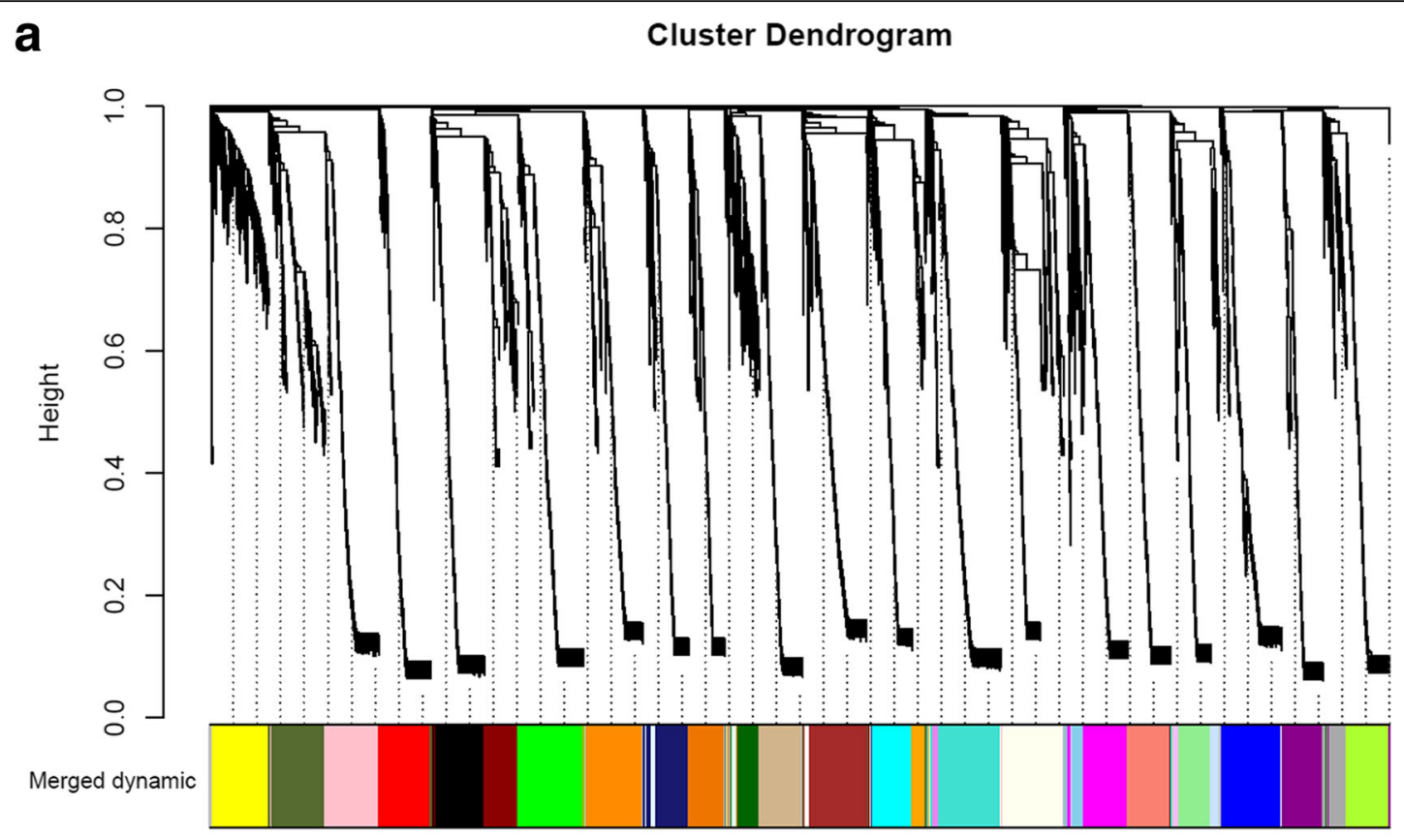

b

Module-trait relationships

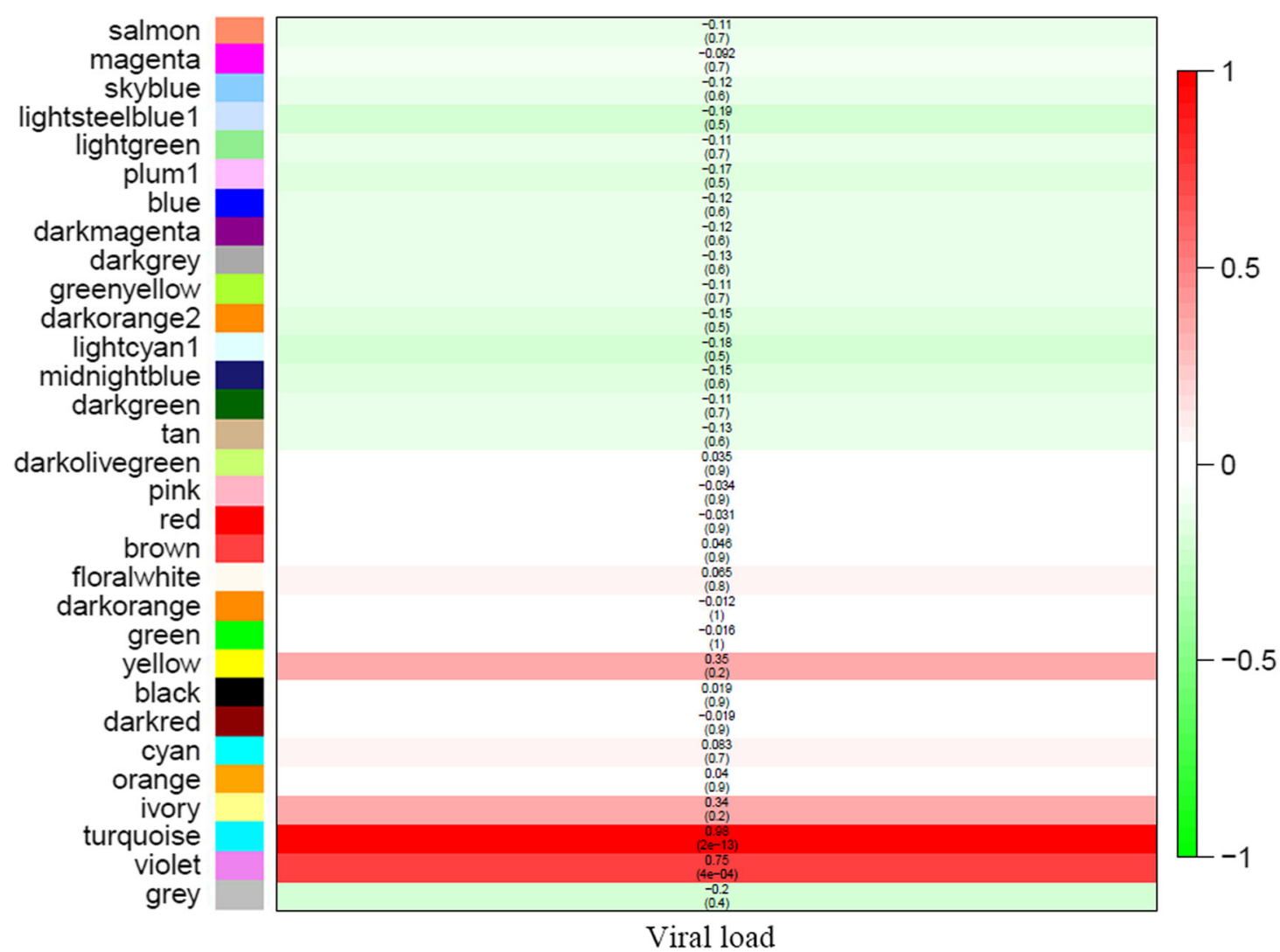

Fig. 6 (See legend on next page.) 
(See figure on previous page.)

Fig. 6 WGCNA identification of gene modules correlated with resistance or susceptibility traits of gibel carp. a The clustering dendrogram of DEUs. Branches represent the co-expressed genes in modules, shown in the colorbar below the dendrogram. $\mathbf{b}$ Heatmap of correlations between modules and viral loads. Each cell contains the corresponding correlation and $p$-value. Positive or negative correlations are denoted in red or green respectively

line of host defense against virus infection [34, 36, 37, 41-47]. After CaHV infection, the up-regulation folds of eight IFN system genes in three gibel carp gynogenetic clones, including retinoic acid-inducible gene I (RIG-I), laboratory of genetics and physiology 2 (LGP2), IFN regulatory factors (IRFs) (IRF1, IRF3, IRF7, and IRF9), $M x$, and viperin, were related to their resistance ability to $\mathrm{CaHV}$, progressively increasing from susceptible clone $\mathrm{A}^{+}$, moderate resistant clone $\mathrm{F}$ to resistant clone $\mathrm{H}$ at 1 dpi [40]. However, immune inhibitory receptor DICPS (diverse Ig domain-containing proteins) showed the opposed expression patterns [48]. Thus, gibel carp might recognize $\mathrm{CaHV}$ products by RIG-I and LGP2, then activate mitochondrial antiviral signaling protein (MAVS)-dependent pathway and induce the expression of IRFs (IRF1, IRF3, IRF7, and IRF9), IFNs and interferon stimulated gene ( $M x$ and viperin) after $C a \mathrm{HV}$ infection [40]. Similarly, a lot of IFN system genes were up-regulated their expression in the survivors of resistant clone $\mathrm{H}$ and F (Table 3), and most of them displayed relatively higher up-regulated folds in clone $\mathrm{H}$ than those in clone $\mathrm{F}$ (Fig. $5)$. Taken together our previous results $[29,40,48]$, we believe that stronger IFN response were triggered and persisted in gibel carp resistant clone $\mathrm{H}$ after $\mathrm{CaHV}$ challenge. The above results also confirmed the critical function of IFN system against viral infection in teleost $[36,42,45,49,50]$. Conversely, the dynamic expression changes in susceptible clone $\mathrm{A}^{+}$are completely different. Many IFN system genes, such as irf3, irf7, lgp2, stat2, $m x 1, m x 3$, viperin, and so on, were down-regulated their expressions in the survivors of susceptible clone $\mathrm{A}^{+}$in comparison with control individuals (Table 3 and Fig. 5). Various viruses have been shown to inhibit the IFN signaling through different escape strategies to promote virus replication and release [51-54]. On the other hand, host might adopt a negative feedback mechanism to respond excessive and long-term IFN stimulation, which prevents inappropriate antiviral reactions and autoimmunity [55-57]. For example, compared to wildtype (WT), the expression levels of IFN-signal modulators (stat1b, stat2, mad5, mita, irf3, and ifr 9), ISGs ( $m x$, gigla, isg15, and isg56) and ifn $\lambda$ were down-regulated in IFNd-Tg fish, a transgenic medaka (Oryzias latipes) that constitutively overexpressed the ifnd gene [57]. Different from the immediately up-regulated expression of IFN system genes in resistant clone $\mathrm{H}$ at $1 \mathrm{dpi}$, most of them were up-regulated at 3-5 dpi in susceptible clone $\mathrm{A}^{+}$
[40], indicating that the delay of IFN response might affect the expression of IFN system genes in the survivors of susceptible clone $\mathrm{A}^{+}$. In addition, among the top 30 enriched pathways of down-regulated DEUs, 11 pathways in resistant clone $\mathrm{H}$ belonged to "metabolism", but only 1 and 2 pathways involved in "metabolism" were found in clone $\mathrm{A}^{+}$and $\mathrm{F}$ (Fig. $3 \mathrm{~g}-\mathrm{i}$ ). The result indicates that the up-regulation of IFN may down-regulated metabolism, consistent with the phenomenon in mouse $[58,59]$.

Interestingly, myosins were identified as positively co-expression module correlated to $\mathrm{CaHV}$ viral loads by WGCNA analysis (Fig. 6 and Additional file 9: Table S7). Myosins are composed of a large superfamily of proteins with similar structures and act as actin-based motor [60]. Viral infections induces dramatic cytoskeletal reorganization, and virion movement is mediated by myosin motors [61-64]. For example, Myh9 can transport infectious viral RNA from cell to cell to accelerate intercellular viral spread [65-67], and can inhibit RhoA signaling, resulting in increased virus release and more viral spread [68]. Moreover, the microRNAs (miRNAs) encoded by the introns of some myosin genes can suppress the expression of IFN 22 and IFN $\lambda 3$ and type I IFN receptor chain IFNAR1 to support viral persistence [69, 70]. In this study, we observed many myosin genes, including $m y h 9$, were up-regulated in the survivors of susceptible clone $\mathrm{A}^{+}$(Table 3; Additional file 8: Table S6), consistent with the down-regulated expression of IFN system genes (Table 3; Additional file 8: Table S6). Additionally, few myosin genes were identified as up-regulated DEUs in the survivors of resistant clone $\mathrm{H}$ and $\mathrm{F}$ in which the expression of IFN system genes were up-regulated (Fig. 5; Table 3; Additional file 8: Table S6). The above results reveal the intrinsic connections among myosins, IFN response and $\mathrm{CaHV}$ viral loads which awaits further investigation.

Besides the distinct expression changes of IFN system genes, we also observed the differential reaction of adaptive immunity to $\mathrm{CaHV}$ among three gynogentic clones (Fig. 5; Table 3; Additional file 8: Table S6). Furthermore, we identified Igs as negatively co-expression module correlated to $\mathrm{CaHV}$ viral loads (Fig. 6; Additional file 8: Table S7). Like mammals, teleost adaptive immune systems include recombination activating gene (RAG), Igs, T cell receptors (TCR) and major histocompatibility complex (MHC) molecules [39, 71]. Igs are specifically produced 
by $\mathrm{B}$ lymphocytes and play pivotal roles in adaptive immunity. They have evolved highly diversified molecules toward recognizing a remarkably large number of antigens to mediate the intracellular neutralization of viruses [7274]. In teleost, several Igs, such as IgL, IgM, IgD and IgZ, were identified [39, 75-78]. In this study, 43 and 33 up-regulated DEUs annotated as members of Ig superfamily were screened from resistant clone $\mathrm{H}$ and susceptible clone $\mathrm{A}^{+}$respectively, while a total of 118 down-regulated DEUs were classified into Ig superfamily in clone $\mathrm{F}$ (Table 3; Additional file 8: Table S6). The host relies on the synergistic action of innate immune system and adaptive immune system, and simultaneously activates the resistance mechanism and disease tolerance strategy to reduce the amount of viruses in the host and the damage of the host parenchyma [79]. Disease tolerance does not exert a direct negative effect on the host viral loads and depends on tissue damage control mechanisms which also regulated by innate and adaptive components of the immune system $[80,81]$. The activation of IFN signaling can not only inhibit viral replication and release [82-84], but also activate lymphocytes, natural killer (NK) cells, and macrophages [85]. IFN is believed acting as the bridge between innate and adaptive immunity $[86,87]$. The activation of both innate immune system and adaptive immune system might be the reason for the highest resistant ability of clone $\mathrm{H}$. Interestingly, the survivors of moderately resistant clone $\mathrm{F}$ kept the activation of innate immune system but the impaired adaptive immune system (Table 3; Additional file 8: Table S6). This similar pattern of immune response was also been found in gilthead seabream (Sparus aurata L.) infected with lymphocystis disease virus (LCDV) [88]. Among the top 30 pathways enriched by DEUs specifically up-regulated their expression levels in the survivors of clone F, two-thirds of pathways belonged to "metabolism" or "biogenesis" (Fig. 3e) which suggested that clone F might actively repair the impairment, including adaptive immune system. Along with the divergence of cyclostomes and cartilaginous fish, adaptive immunity emerged in vertebrate around 450 million years ago $[89,90]$. However, it is believed that the innate immunity plays the dominant role in resistance to viral infection in teleost, due to the highly specialized immune responses (which means limited recognition of pathogens), low antibody affinity, slow antibody response, and weak memory response in fish adaptive immunity [39, 71, 91]. Therefore, the clone F showed moderate resistant ability to $\mathrm{CaHV}$, which is weaker than that of clone H (IFN system genes and Ig genes both up-regulated their expression) and higher than that of clone $\mathrm{A}^{+}$(IFN system genes down-regulated and Ig genes up-regulated their expression). Moreover, susceptible clone $\mathrm{A}^{+}$failed to trigger IFN antiviral response but activated myosins to increase the virus release and spread (Table 3; Additional file 8: Table S6), which resulted in the loss of battle between host and $\mathrm{CaHV}$ and severely impaired circulatory system (Fig. 5f). Thus, the further analysis are necessary to confirm the differential innate and adaptive immune responses, to reveal the association among IFN system, myosin, Igs and disease resistance/ susceptibility among three gibel carp clones.

\section{Conclusions}

The current study represents a paradigm of differential innate and adaptive immune reactions among fishes with distinct resistance to virus. Our results suggest that the differential regulation mechanism between innate and adaptive immunity may be the key reason for the distinct resistance to $\mathrm{CaHV}$ among the three gibel carp gynogenetic clones. The establishments of three gibel carp gynogenetic clones with distinct resistances to $\mathrm{CaHV}$ will provide a model to definitely clarify the regulatory interactions among IFN signaling, Igs, myosins and virus in teleost. In addition, our studies will be helpful to the disease-resistance breeding of gibel carp.

\section{Methods \\ $\mathrm{CaHV}$ infection and sample collection}

Six month old gibel carps were collected from the GuanQiao Experimental Station, Institute of Hydrobiology, Chinese academy of sciences. The $\mathrm{CaHV}$ challenge experiments and the confirmation of control individuals with $\mathrm{CaHV}$ free were performed as previously described $[29,40]$. The mortalities caused by CaHV subsided after $14 \mathrm{dpi}$, and the $\mathrm{CaHV}$ challenge experiment was terminated at 28 dpi. Head-kidney tissues were collected from control fishes and healthy survivors at $28 \mathrm{dpi}$. All samples were preserved in RNAlater (QIAGEN) and stored at $-20^{\circ} \mathrm{C}$ for nucleic acid extraction. All procedures in this study were performed following the ethical requirements of Animal Care and Use Committee of Institute of Hydrobiology, Chinese Academy of Sciences to minimize animal suffering. After deep and overdosed anesthesia with styrylpyridine $(30-50 \mathrm{mg} / \mathrm{L}$; aladdin, China), the fish were euthanized by immediately cutting off the spinal cord adjacent to the head.

\section{CaHV detection and quantification}

Three control individuals, diseased individuals or survivors of each clone were selected to evaluate viral load. Total DNA was isolated using DNA extraction kit (Promega, USA) following the manufacturer's protocol. Five genes, including hel, cap, ung, dut, and tmk, were selected to detect the existence of $\mathrm{CaHV}$. The primers were designed according to the $\mathrm{CaHV}$ genome sequence (KU199244) (Additional file 10: Table S8). Amplification was performed in $25 \mu \mathrm{L}$ PCR mixture containing $100 \mathrm{ng}$ of template DNA, $0.2 \mathrm{mM}$ of each primer, $1.5 \mathrm{mM}$ of $\mathrm{MgCl}_{2}, 0.2 \mathrm{mM}$ of each dNTP, $2.5 \mu \mathrm{L}$ of $10 \times$ Taq buffer, and 1 unit of Taq DNA 
polymerase (Thermo Fisher Scientific, USA). The PCR amplification was performed with an initial denaturation for $3 \mathrm{~min}$ at $95^{\circ} \mathrm{C}$, followed by 40 cycles of denaturation for $30 \mathrm{~s}$ at $95^{\circ} \mathrm{C}$, annealing for $30 \mathrm{~s}$ at $60^{\circ} \mathrm{C}$, extension for $45 \mathrm{~s}$ at $72{ }^{\circ} \mathrm{C}$ and a final extension for $5 \mathrm{~min}$ at $72{ }^{\circ} \mathrm{C}$. The PCR products were analyzed by agarose gel electrophoresis. $\beta$-actin was selected as reference gene (Additional file 10: Table S8). Viral load were evaluated by real-time PCR as previously described [29, 40, 92]. Briefly, a 637 bp fragment of $\mathrm{CaHV}$ helicase gene was amplified, purified and inserted into the pMD18-T plasmid to produce pMD-CaHV (3329 bp). Then, pMD-CaHV was diluted into 10 -fold dilution series and used as the standard template of $\mathrm{CaHV}$ to preform quantitative real-time PCR as previously described [92].

\section{RNA sequencing, assembly, annotation and differential expression analysis}

To avoid the individual differences in virus susceptibility, head-kidney tissues from three survivor with similar average viral load (10 particles/ng DNA) of each clone were collected for RNA-Seq. The RNA isolation, library construction and sequencing were performed as previously described [29]. Briefly, the total RNAs were isolated by using SV Total RNA isolation System (Promega, USA) and assessed their quantity and quality by Agilent 2100 Bioanalyzer. The library construction, Hiseq $4000^{\mathrm{m}}$ sequencing, De novo assembly, screening and functional annotation of DEUs were accomplished by Beijing Genomics Institute (BGI), China. Firstly, total RNAs were digested by Dnase I (NEB), purified by oligo-dT beads (Invitrogen) and fragmented with Fragment buffer (Ambion). Then, the first and second strand cDNAs were synthesized successively by First Strand Master Mix and Second Strand Master Mix (Invitrogen) respectively, and purified and combined with End Repair Mix. After purified and mixed with A-Tailing Mix, Adenylate 3'Ends DNA, and Adapter and Ligation Mix, DNA fragments between $300 \mathrm{bp}-350 \mathrm{bp}$ were selected and enriched. The final libraries were quantified by real-time qPCR (TaqMan Probe) and were amplified on cBot to generate the cluster on the flowcell. Finally, the amplified flowcells were sequenced on the Illumina Hiseq platform to generate $150 \mathrm{bp}$ single-end reads. The raw sequencing reads were filtered to remove the reads with low quality or adaptors to obtain clean reads, which then were assembled into unigenes by Trinity [93] and Tgicl [94]. Subsequently, these unigenes were annotated with National Center for Biotechnology Information (NCBI) non-redundant protein (NR), NCBI non-redundant nucleotide (NT), GO, Clusters of Orthologous Groups of proteins (COG), KEGG, InterPro and Swiss-Prot database using Blast2GO [95], and InterPro database using InterProScan5 [96].
Clean reads were mapped to unigenes using Bowtie2 [97] and the expression levels of unigenes were calculated by RSEM (RNA-Seq by Expectation Maximization) [98] and DEUs were identified with NOIseq based on noisy distribution model [99]. The threshold to judge the significant difference was defined as "relative change $\geq 2$ and probability $\geq 0.8$ ". KEGG enrichment analysis of DEUs was performed by phyper, a function of R. False discovery rate (FDR) was used to determine the threshold of $p$ value and KEGG terms $(\mathrm{FDR} \leq 0.01)$ were considered significantly enriched. Venn and heatmap diagram were generated by using jvenn [100] and $\mathrm{MeV}$, respectively.

\section{Weighted gene correlation network analysis (WGCNA)}

To figure out the relationship between DEUs and viral loads, WGCNA was carried out by the WGCNA R package $[101,102]$. Expression correlation coefficients of all DEUs were firstly calculated and a suitable soft threshold was chosen to build gene networks by using the scale-free topology criterion. Subsequently, based on the hierarchical clustering built by the topological overlap matrix and using the dynamic tree cut method, the co-expression modules were identified (minModuleSize $=30$ and mergeCutHeight $=0.25$ ). Then, the module eigengenes (MEs) were determined by using the expression data within each module and the module-trait relationships were calculated based on the correlations between MEs and viral loads of samples.

\section{Quantitative reverse transcription PCR (qPCR)}

The head kidney tissues of three control individuals or survivors of each clone were selected to perform qPCR. The total RNA isolation and first-strand cDNAs synthesis were performed according to the previous description [29, 40,103]. According to the sequences of the de novo assembly data (SRP096800), the primers were designed (Additional file 10: Table S8). qPCR was performed in the CFX96 ${ }^{\text {m }}$ Real-Time PCR System (Bio-Rad) by using iTaq $^{\text {Tm }}$ Universal SYBR $^{\circ}$ Green Supermix (Bio-Rad, USA). The reaction system, PCR protocols and negative control selection were also performed as described previously [29, 40]. All samples were analyzed in triplicate, and the relative expression levels were calculated by using the $2^{-\Delta \Delta C T}$ method. Tukey's test was calculated with SPSS software (SPSS Inc.) for statistical analysis. A probability (p) of $<0.05$ was considered statistically significant. According to the screening results of optimal reference gene [40], eukaryotic translation elongation factor 1 alpha 1, like 1 (eef1a1l1) $(\mathrm{M}$ value $=0.74<1.5)$, was used as the normalizer for qPCR. 


\section{Additional files}

Additional file 1: Table S1. Summary statistics of sequencing data. Quality of sequencing reads, transcripts and unigenes are shown respectively. The number 1,2 and 3 represent three replicate samples of each group. (XLSX $12 \mathrm{~kb}$ )

Additional file 2: Table S2. Differentially expressed unigenes (DEUs) (Probability $\geq 0.8$ and relative change $\geq 2$ ) in $s^{-} A^{+}$vs $c-A^{+}, s-F$ vs C-F and s$\mathrm{H}$ vs $\mathrm{C}-\mathrm{H}$. Lists of DEUs include Unigene ID, Length, FPKM, $\log _{2}$ fold change, $P$ value, up- or down-regulation and annotation. (XLSX 1172 kb)

Additional file 3: Figure S1. The numbers of differentially expressed unigenes (DEUs) from s- $\mathrm{A}^{+}$vs $\mathrm{c}-\mathrm{A}^{+}$, s- $\mathrm{F}$ vs $\mathrm{c}-\mathrm{F}$ and $\mathrm{s}-\mathrm{H}$ vs $\mathrm{c}-\mathrm{H}$. The red and green bars indicate up- and down-regulated DEUs respectively. (TIF 89 $\mathrm{kb})$

Additional file 4: Figure S2. KEGG pathway enrichment analysis. a-c Top 10 enriched KEGG pathways of DEUs from s-H vs c-H (a), s-F vs c-F (b) and $\mathrm{s}-\mathrm{A}^{+} \mathrm{vs} \mathrm{c}-\mathrm{A}^{+}$(c). The $\mathrm{x}$-axis indicates the rich factor of each pathway and $y$-axis shows pathway. The color and size of dot indicates $Q$ value and the number of DEUs assigned to the corresponding pathway respectively. (TIF $1300 \mathrm{~kb}$ )

Additional file 5: Table S3. Enriched KEGG pathways in $\mathrm{s}-\mathrm{A}^{+} \vee \mathrm{s} \mathrm{C}-\mathrm{A}^{+}$, sF vs C-F and s-H vs C-H. KEGG pathway description, number of DEUs assigned to the corresponding pathway, P value, Q value, Pathway ID, KEGG function classification, annotated KO ID of DEUs and unigene ID assigned to the corresponding pathway are shown. (XLSX $153 \mathrm{~kb}$ )

Additional file 6: Table S4. The common and unique differentially expressed unigenes (DEUs) in $\mathrm{s}-\mathrm{A}^{+}$vs $\mathrm{c}-\mathrm{A}^{+}$, s-F vs $\mathrm{c}-\mathrm{F}$ and $\mathrm{s}-\mathrm{H}$ vs $\mathrm{c}-\mathrm{H}$. List of DEUs includes Unigene ID, FPKM, $\log _{2}$ fold change, up- or downregulation and annotation. (XLSX $810 \mathrm{~kb}$ )

Additional file 7: Table S5. Enriched KEGG pathways of DEUs commonly up- and down-regulated in three clones and specifically upand down-regulated in s- $\mathrm{A}^{+}$vs $\mathrm{c}-\mathrm{A}^{+}$, s- $\mathrm{F}$ vs $\mathrm{c}-\mathrm{F}$ and $\mathrm{s}-\mathrm{H}$ vs $\mathrm{c}-\mathrm{H}$. KEGG pathway description, number of DEUs assigned to the corresponding pathway, P value, Q value, Pathway ID, KEGG function classification, annotated $\mathrm{KO}$ ID of DEUs and unigene ID assigned to the corresponding pathway are shown. (XLSX $188 \mathrm{~kb}$ )

Additional file 8: Table S6. Up-/down-regulated DEUs annotated as IFN system genes, immunoglobulins and members of myosin superfamily in ${\mathrm{s}-\mathrm{A}^{+}}^{\mathrm{V}} \mathrm{s} \mathrm{c}-\mathrm{A}^{+}, \mathrm{s}-\mathrm{F}$ vs $\mathrm{c}-\mathrm{F}$ and $\mathrm{s}-\mathrm{H}$ vs $\mathrm{c}-\mathrm{H}$. List of DEUs includes Unigene ID, FPKM, $\log _{2}$ fold change, up- or down-regulation and annotation. (XLSX $67 \mathrm{~kb})$

Additional file 9: Table S7. DEUs in the turquoise and lightsteelbiue1 modules. List of DEUs includes Unigene ID, Module, Correlation, P value and annotation. (XLSX $62 \mathrm{~kb}$ )

Additional file 10: Table S8. Primers used in this study. (XLSX $11 \mathrm{~kb}$ )

\section{Abbreviations}

alas2: Delta-aminolevulinate synthase; alox15: Arachidonate 15-lipoxygenase; ank1: Ankyrin 1; birc6: Baculoviral IAP repeat-containing protein 6; blvrb: Flavin reductase; CaHV: Carassius auratus herpesvirus; cahz: Carbonic anhydrase; cap: Capsid triplex subunit 2; COG: Clusters of Orthologous Groups of proteins; cpox: Coproporphyrinogen oxidase; DEUs: Differentially expressed unigenes; DICP: Diverse Ig domain-containing protein; dpi: Days post injection; dut: Deoxyuridine triphosphatase; eef1a1/1: Eukaryotic translation elongation factor 1 alpha 1, like 1; fam210b: Family with sequence similarity 210 member B; fech: Ferrochelatase; gbp: Guanylate-binding protein; gig: Grass carp hemorrhagic virus-induced gene; GO: Gene Ontology; gvinp 1: Interferon-induced very large GTPase 1; hba: Hemoglobin alpha; hbb: Hemoglobin beta; hel: Helicase-primase helicase subunit; hemge: Hemogen; hmbs: Hydroxymethylbilane synthase b; huwe1: E3 ubiquitin-protein ligase huwe1; ifi: Interferon-induced protein; ifitm 1: Interferon-induced transmembrane protein 1; IFN: Interferon; ifny: Interferon gamma; IgD: Immunoglobulin D; IgLK: Immunoglobulin kappa; IgLA: Immunoglobulin lambda; IgM: Immunoglobulin $M_{;}$

Igs: Immunoglobulins; IgZ: Immunoglobulin Z; irf: Interferon regulatory factor; IRFs: IFN regulatory factors; irgc: Interferon-inducible GTPase 5; isg15: Interferon-stimulated gene 15; ISGs: Interferon stimulated genes;
KEGG: Kyoto Encyclopedia of Genes and Genomes; klf: Kruppel-like factor; LCDV: Lymphocystis disease virus; lgp2: Laboratory of genetics and physiology 2; MAVS: Mitochondrial antiviral signaling protein; mfrn 1: Mitoferrin-1; MHC: Major histocompatibility complex; miRNAs: microRNAs; $m t 1$ : Metallothionein; $m x$ : Interferon-induced GTPbinding protein; mycbp2: E3 ubiquitin-protein ligase mycbp2; myh7: Myosin7; myha: Myosin heavy chain a; myhb: Myosin heavy chain b; myl: Myosin light chain; myo18a: Myosin-XVIIla; myo3b: Myosin-IIIb; NCBI: National Center for Biotechnology Information; nf1: Nuclear factor l; NK: Natural killer; nlrp: NACHT, LRR and PYD domains-containing protein; NR: NCBI nonredundant protein; NT: NCBI non-redundant nucleotide; plgRL: Polymeric immunoglobulin receptor-like; pikks: Phosphatidylinositol 3-kinase-related kinase; pla2g4b: Cytosolic phospholipase A2 beta; RAG: Recombination activating gene; RIG-I: Retinoic acid-inducible gene I; RSEM: RNA-Seq by Expectation Maximization; s/c10a4: Sodium/bile acid cotransporter 4; slc4a1: Band 3 anion transport protein; spen: Msx2-interacting protein; sptb: Spectrin beta; stab1: Stabilin-1; stat: Signal transducer and activator of transcription; TCR: T cell receptors; tfr: Transferrin receptor; t/r: Toll-like receptor; tmk: Thymidylate kinase; ung: Uracil-DNA glycosylase; urod: Uroporphyrinogen decarboxylase; vps13c: Vacuolar protein sortingassociated protein 13C; wdfy4: WD repeat and FYVE domain-containing protein 4; WGCNA: Weighted gene correlation network analysis; WT: Wildtype

\section{Acknowledgements}

None.

\section{Funding}

This work was supported by the Strategic Priority Research Program of the Chinese Academy of Sciences (XDA08030202 and XDA08030201), the National Natural Science Foundation (31772838) and the earmarked fund for Modern Agro-industry Technology Research System (NYCYTX-49). The funding bodies had no role in the design of the study and collection, analysis, and interpretation of data and in writing the manuscript.

\section{Availability of data and materials}

The raw data supporting the conclusions of this article is available in the NCBI database under the accession number SRP096800.

\section{Authors' contributions}

WJL and FXG performed laboratory experiments, analyzed the data and drafted the manuscript. YW participated in the data analysis and revised manuscript. ZL participated in the sample collection. QYZ identified the $\mathrm{CaHV}$ and conceived the study. XJZ participated in the data analysis. LZ designed the studies, analyzed the data, and drafted the manuscript. JFG conceived the study and revised the manuscript. All authors have read and approved the manuscript.

\section{Ethics approval and consent to participate}

Gibel carps (Carassius gibelio) were obtained from the GuanQiao Experimental Station, Institute of Hydrobiology, Chinese academy of sciences, which is located in Wuhan, China. All procedures in this research were performed with the approval of Animal Care and Use Committee of Institute of Hydrobiology, Chinese Academy of Sciences.

\section{Consent for publication}

Not applicable.

\section{Competing interests}

The authors declare that they have no competing interests.

\section{Publisher's Note}

Springer Nature remains neutral with regard to jurisdictional claims in published maps and institutional affiliations.

\section{Author details}

${ }^{1}$ State Key Laboratory of Freshwater Ecology and Biotechnology, Institute of Hydrobiology, The Innovation Academy of Seed Design, Chinese Academy of Sciences, Wuhan 430072, Hubei, China. ${ }^{2}$ University of Chinese Academy of Sciences, Beijing 100049, China. Institute of Marine Biology, College of Oceanography, Hohai University, Nanjing 210098, China. 


\section{Received: 28 January 2019 Accepted: 7 May 2019} Published online: 28 May 2019

\section{References}

1. Gui JF, Zhou L. Genetic basis and breeding application of clonal diversity and dual reproduction modes in polyploid Carassius auratus gibelio. Sci China Life Sci. 2010;53:409-15.

2. Zhou L, Gui JF. Natural and artificial polyploids in aquaculture. Aquac Fish. 2017;2:103-11

3. Abramenko MI, Nadtoka EV, Makhotkin MA, Kravchenko OV, Poltavtseva TG. Distribution and cytogenetic features of triploid male goldfish from Azov basin. Ontogenez. 2004;35:375-86.

4. Jiang FF, Wang ZW, Zhou L, Jiang L, Zhang XJ, Apalikova OV, Brykov VA, Gui JF. High male incidence and evolutionary implications of triploid form in Northeast Asia Carassius auratus complex. Mol Phylogenet Evol. 2013;66: 350-9.

5. Liu XL, Jiang FF, Wang ZW, Li XY, Li Z, Zhang XJ, Chen F, Mao JF, Zhou L, Gui JF. Wider geographic distribution and higher diversity of hexaploids than tetraploids in Carassius species complex reveal recurrent polyploidy effects on adaptive evolution. Sci Rep. 2017;7:5395.

6. Liu XL, Li XY, Jiang FF, Wang ZW, Li Z, Zhang XJ, Zhou L, Gui JF. Numerous mitochondrial DNA haplotypes reveal multiple independent polyploidy origins of hexaploids in Carassius species complex. Ecol Evol. 2017;7:10604-15.

7. Sakai H, lguchi K, Yamazaki Y, Sideleva VG, Goto A. Morphological and mtDNA sequence studies on three crucian carps (Carassius: Cyprinidae) including a new stock from the Ob River system, Kazakhstan. J Fish Biol. 2009;74:1756-73.

8. Takada M, Tachihara K, Kon T, Yamamoto G, Iguchi K, Miya M, Nishida M. Biogeography and evolution of the Carassius auratus-complex in East Asia. BMC Evol Biol. 2010;10:7.

9. Toth B, Varkonyi E, Hidas A, Meleg EE, Varadi L. Genetic analysis of offspring from intra- and interspecific crosses of Carassius auratus gibelio by chromosome and RAPD analysis. J Fish Biol. 2005;66:784-97.

10. Jiang YG, Liang SC, Chen BD, Yu HC, Shan SX, Yang SE, Lin DL, Shen GQ. Biological effect of heterologous sperm on gynogenetic offspring in Carassius auratus gibelio. Acta Hydrobiologica Sinica. 1983;8:1-13.

11. Li XY, Gui JF. Diverse and variable sex determination mechanisms in vertebrates. Sci China Life Sci. 2018;61:1503-14.

12. Zhang J, Sun M, Zhou L, Li Z, Liu Z, Li XY, Liu XL, Liu W, Gui JF. Meiosis completion and various sperm responses lead to unisexual and sexual reproduction modes in one clone of polyploid Carassius gibelio. Sci Rep. 2015:5:10898.

13. Zhou L, Wang Y, Gui JF. Genetic evidence for gonochoristic reproduction in gynogenetic silver crucian carp (Carassius auratus gibelio bloch) as revealed by RAPD assays. J Mol Evol. 2000;51:498-506.

14. Li XY, Liu XL, Ding M, Li Z, Zhou L, Zhang XJ, Gui JF. A novel male-specific SET domain-containing gene setdm identified from extra microchromosomes of gibel carp males. Sci Bull. 2017;62:528-36.

15. Li XY, Liu XL, Zhu YJ, Zhang J, Ding M, Wang MT, Wang ZW, Li Z, Zhang XJ, Zhou $L$, et al. Origin and transition of sex determination mechanisms in a gynogenetic hexaploid fish. Heredity. 2018;121:64-74.

16. Li XY, Zhang QY, Zhang J, Zhou L, Li Z, Zhang XJ, Wang D, Gui JF. Extra microchromosomes play male determination role in polyploid gibel carp. Genetics. 2016;203:1415-24.

17. Zhou L, Wang ZW, Wang Y, Gui JF. Crucian carp and gibel carp culture. In: Gui JF, Tang QS, Li ZJ, Liu JS, De Silva SS, editors. Aquaculture in China: success stories and modern trends. Oxford: Wiley; 2018. p. 149-57.

18. Bureau of Fisheries, Ministry of Agriculture of the People's Republic of China. China Fishery Statistical Yearbook. Bejing: China Agriculture Press; 2018.

19. Zeng XT, Chen ZY, Deng YS, Gui JF, Zhang QY. Complete genome sequence and architecture of crucian carp Carassius auratus herpesvirus (CaHV). Arch Virol. 2016;161:3577-81.

20. Goodwin AE, Merry GE, Sadler J. Detection of the herpesviral hematopoietic necrosis disease agent (Cyprinid herpesvirus 2) in moribund and healthy goldfish: validation of a quantitative PCR diagnostic method. Dis Aquat Org. 2006;69:137-43.

21. Hanson L, Dishon A, Kotler M. Herpesviruses that infect fish. Viruses. 2011;3: 2160-91.

22. Hedrick RP, Gilad O, Yun S, Spangenberg JV, Marty GD, Nordhausen RW, Kebus MJ, Bercovier H, Eldar A. A herpesvirus associated with mass mortality of juvenile and adult koi, a strain of common carp. J Aquat Anim Health. 2000;12:44-57.

23. McAllister A, Tangy F, Aubert C, Brahic M. Molecular cloning of the complete genome of Theiler's virus, strain DA, and production of infectious transcripts. Microb Pathog. 1989;7:381-8.

24. Zhang QY, Gui JF. Virus genomes and virus-host interactions in aquaculture animals. Sci China Life Sci. 2015;58:156-69.

25. Zhang QY, Gui JF. Diversity, evolutionary contribution and ecological roles of aquatic viruses. Sci China Life Sci. 2018;61:1486-502.

26. Zhou L, Gui JF. Applications of genetic breeding biotechnologies in Chinese aquaculture. In: Gui JF, Tang QS, Li ZJ, Liu JS, De Silva SS, editors. Aquaculture in China: success stories and modern trends. Oxford: John Wiley \& Sons Ltd; 2018. p. 465-96.

27. Wang ZW, Zhu HP, Wang D, Jiang FF, Guo W, Zhou L, Gui JF. A novel nucleo-cytoplasmic hybrid clone formed via androgenesis in polyploid gibel carp. BMC Res Notes. 2011;4:82

28. Yi MS, Li YQ, Liu JD, Zhou L, Yu QX, Gui JF. Molecular cytogenetic detection of paternal chromosome fragments in allogynogenetic gibel carp, Carassius auratus gibelio Bloch. Chromosom Res. 2003;11:665-71.

29. Gao FX, Wang Y, Zhang QY, Mou CY, Li Z, Deng YS, Zhou L, Gui JF. Distinct herpesvirus resistances and immune responses of three gynogenetic clones of gibel carp revealed by comprehensive transcriptomes. BMC Genomics. 2017;18:561.

30. Gui JF. Fish biology and biotechnology is the source for sustainable aquaculture. Sci China Life Sci. 2015;58:121-3.

31. Skamene E, Pietrangeli CE. Genetics of the immune response to infectious pathogens. Curr Opin Immunol. 1991;3:511-7.

32. Wiegertjes GF, Groeneveld A, Muiswinkel WB. Genetic variation in susceptibility to Trypanoplasma borreli infection in common carp (Cyprinus carpio L.). Vet Immunol Immunopathol. 1995;47:153-61.

33. Wiegertjes GF, Stet RJ, Parmentier HK, van Muiswinkel WB. Immunogenetics of disease resistance in fish: a comparative approach. Dev Comp Immunol. 1996;20:365-81.

34. Gui JF, Zhu ZY. Molecular basis and genetic improvement of economically important traits in aquaculture animals. Chin Sci Bull. 2012;57:1751-60.

35. Litman GW, Cannon JP, Rast JP. New insights into alternative mechanisms of immune receptor diversification. Adv Immunol. 2005;87:209-36.

36. Sunyer JO. Fishing for mammalian paradigms in the teleost immune system. Nat Immunol. 2013;14:320-6.

37. Zhang YB, Gui JF. Molecular regulation of interferon antiviral response in fish. Dev Comp Immunol. 2012;38:193-202.

38. Bonilla FA, Oettgen HC. Adaptive immunity. J Allergy Clin Immunol. 2010; 125:33-40.

39. Rauta PR, Nayak B, Das S. Immune system and immune responses in fish and their role in comparative immunity study: a model for higher organisms. Immunol Lett. 2012;148:23-33.

40. Mou CY, Wang Y, Zhang QY, Gao FX, Li Z, Tong JF, Zhou L, Gui JF. Differential interferon system gene expression profiles in susceptible and resistant gynogenetic clones of gibel carp challenged with herpesvirus CaHV. Dev Comp Immunol. 2018;86:52-64.

41. Feng $H$, Zhang YB, Zhang QM, Li Z, Zhang QY, Gui JF. Zebrafish IRF1 regulates IFN antiviral response through binding to IFN $\varphi 1$ and IFN $\varphi 3$ promoters downstream of MyD88 signaling. J Immunol. 2015;194:1225-38.

42. Kim BH, Chee JD, Bradfield CJ, Park ES, Kumar P, MacMicking JD. Interferoninduced guanylate-binding proteins in inflammasome activation and host defense. Nat Immunol. 2016;17:481-9.

43. Robertsen B. The interferon system of teleost fish. Fish Shellfish Immunol. 2006;20:172-91.

44. Sadler AJ, Williams BR. Interferon-inducible antiviral effectors. Nat Rev Immunol. 2008:8:559-68.

45. Workenhe ST, Rise ML, Kibenge MJT, Kibenge FSB. The fight between the teleost fish immune response and aquatic viruses. Mol Immunol. 2010:47:2525-36.

46. Zhang QM, Zhao X, Li Z, Wu M, Gui JF, Zhang YB. Alternative splicing transcripts of zebrafish LGP2 gene differentially contribute to IFN antiviral response. J Immunol. 2018;200:688-703.

47. Zou J, Secombes CJ. Teleost fish interferons and their role in immunity. Dev Comp Immunol. 2011;35:1376-87.

48. Gao FX, Lu WJ, Wang Y, Zhang QY, Zhang YB, Mou CY, Li Z, Zhang XJ, Liu $C W$, Zhou $L$, et al. Differential expression and functional diversification of diverse immunoglobulin domain-containing protein (DICP) family in three gynogenetic clones of gibel carp. Dev Comp Immunol. 2018;84:396-407. 
49. Chan T, Barra NG, Lee AJ, Ashkar AA. Innate and adaptive immunity against herpes simplex virus type 2 in the genital mucosa. J Reprod Immunol. 2011; 88:210-8.

50. Langevin C, Aleksejeva E, Passoni G, Palha N, Levraud JP, Boudinot P. The antiviral innate immune response in fish: evolution and conservation of the IFN system. J Mol Biol. 2013;425:4904-20.

51. Chen S, Yang C, Zhang W, Mahalingam S, Wang MS, Cheng AC. Flaviviridae virus nonstructural proteins 5 and $5 \mathrm{~A}$ mediate viral immune evasion and are promising targets in drug development. Pharmacol Therapeut. 2018;190:1-14.

52. Hoffmann HH, Schneider WM, Rice CM. Interferons and viruses: an evolutionary arms race of molecular interactions. Trends Immunol. 2015;36:124-38.

53. Ma Z, Damania B. The CGAS-STING defense pathway and its counteraction by viruses. Cell Host Microbe. 2016;19:150-8.

54. Parvatiyar K, Pindado J, Dev A, Aliyari SR, Zaver SA, Gerami H, Chapon M, Ghaffari AA, Dhingra A, Cheng GH. A TRAF3-NIK module differentially regulates DNA vs RNA pathways in innate immune signaling. Nat Commun. 2018;9:2770.

55. Larner AC, Chaudhuri A, Darnell JE Jr. Transcriptional induction by interferon. New protein(s) determine the extent and length of the induction. J Biol Chem. 1986;261:453-9.

56. Sarasin FM, Wang $X$, Yan M, Duong FH, Poli V, Hilton DJ, Zhang DE, Heim $\mathrm{MH}$. Alpha interferon induces long-lasting refractoriness of JAK-STAT signaling in the mouse liver through induction of USP18/UBP43. Mol Cell Biol. 2009;29:4841-51.

57. Maekawa S, Aoki T, Wang HC. Constitutive overexpressed type I interferon induced downregulation of antiviral activity in medaka fish (Oryzias latipes) Dev Comp Immunol. 2017;68:12-20.

58. Greer RL, Dong XX, Moraes ACF, Zielke RA, Fernandes GR, Peremyslova E, Vasquez-Perez S, Schoenborn AA, Gomes EP, Pereira AC, et al. Akkermansia muciniphila mediates negative effects of IFN gamma on glucose metabolism. Nat Commun. 2016;7:13329.

59. Medzhitov R, Schneider DS, Soares MP. Disease tolerance as a defense strategy. Science. 2012;335:936-41.

60. Lee BS. Myosins in osteoclast formation and function. Biomolecules. 2018;8:157.

61. Durkin CH, Leite F, Cordeiro JV, Handa Y, Arakawa Y, Valderrama F, Way M. RhoD inhibits RhoC-ROCK-dependent cell contraction via PAK6. Dev Cell. 2017:41:315-29.

62. Fritzsche $M$, Lewalle A, Duke T, Kruse K, Charras G. Analysis of turnover dynamics of the submembranous actin cortex. Mol Biol Cell. 2013;24:757-67.

63. Koster DV, Mayor S. Cortical actin and the plasma membrane: inextricably intertwined. Curr Opin Cell Biol. 2016;38:81-9.

64. Taylor MP, Koyuncu OO, Enquist LW. Subversion of the actin cytoskeleton during viral infection. Nat Rev Microbiol. 2011;9:427-39.

65. Guo R, Katz BB, Tomich JM, Gallagher T, Fang Y. Porcine reproductive and respiratory syndrome virus utilizes nanotubes for intercellular spread. J Virol. 2016;90:5163-75.

66. Xiong D, Du Y, Wang HB, Zhao B, Zhang H, Li Y, Hu LJ, Cao JY, Zhong Q, Liu WL, et al. Nonmuscle myosin heavy chain $\| A$ mediates EpsteinBarr virus infection of nasopharyngeal epithelial cells. PNAS. 2015;112: 11036-41

67. Arii J, Goto H, Suenaga T, Oyama M, Kozuka-Hata H, Imai T, Minowa A Akashi $\mathrm{H}$, Arase $\mathrm{H}$, Kawaoka Y, et al. Non-muscle myosin IIA is a functional entry receptor for herpes simplex virus-1. Nature. 2010;467:859-62.

68. Handa Y, Durkin CH, Dodding MP, Way M. Vaccinia virus F11 promotes viral spread by acting as a PDZ-containing scaffolding protein to bind myosin-9A and inhibit RhoA signaling. Cell Host Microbe. 2013;14:51-62

69. McFarland AP, Horner SM, Jarret A, Joslyn RC, Bindewald E, Shapiro BA, Delker DA, Hagedorn CH, Carrington M, Gale M, et al. The favorable IFNL3 genotype escapes mRNA decay mediated by AU-rich elements and hepatitis C virus-induced microRNAs. Nat Immunol. 2014;15:72-9.

70. Jarret A, McFarland AP, Horner SM, Kell A, Schwerk J, Hong M, Badil S, Joslyn RC, Baker DP, Carrington M, et al. Hepatitis-C-virus-induced microRNAs dampen interferon-mediated antiviral signaling. Nat Med. 2016 22:1475-81.

71. Wilson $\mathrm{AB} . \mathrm{MHC}$ and adaptive immunity in teleost fishes. Immunogenetics. 2017;69:521-8

72. Bomsel M, Heyman M, Hocini H, Lagaye S, Belec L, Dupont C, Desgranges C. Intracellular neutralization of HIV transcytosis across tight epithelial barriers by anti-HIV envelope protein dlgA or IgM. Immunity. 1998;9:277-87.
73. Strugnell RA, Wijburg OLC. The role of secretory antibodies in infection immunity. Nat Rev Microbiol. 2010;8:656-67.

74. Cerutti A, Rescigno M. The biology of intestinal immunoglobulin a responses. Immunity. 2008;28:740-50.

75. Hansen JD, Landis ED, Phillips RB. Discovery of a unique Ig heavy-chain isotype ( $\lg T$ ) in rainbow trout: implications for a distinctive B cell developmental pathway in teleost fish. PNAS. 2005;102:6919-24.

76. Ohta $Y$, Flajnik M. IgD, like $\operatorname{lgM}$, is a primordial immunoglobulin class perpetuated in most jawed vertebrates. PNAS. 2006;103:10723-8.

77. Randelli E, Buonocore F, Scapigliati G. Cell markers and determinants in fish immunology. Fish Shellfish Immunol. 2008;25:326-40.

78. Zhu LY, Nie L, Zhu G, Xiang LX, Shao JZ. Advances in research of fish immune-relevant genes: a comparative overview of innate and adaptive immunity in teleosts. Dev Comp Immunol. 2013;39:39-62.

79. Soares MP, Teixeira L, Moita LF. Disease tolerance and immunity in host protection against infection. Nat Rev Immunol. 2017;17:83-96.

80. O'Rourke RW, White AE, Metcalf MD, Winters BR, Diggs BS, Zhu XX, Marks $\mathrm{DL}$. Systemic inflammation and insulin sensitivity in obese IFN-gamma knockout mice. Metabolism. 2012;61:1152-61.

81. Kotas ME, Medzhitov R. Homeostasis, inflammation, and disease susceptibility. Cell. 2015:160:816-27.

82. $L i \mathrm{X} L$, Blackford JA, Hassel BA. RNase $L$ mediates the antiviral effect of interferon through a selective reduction in viral RNA during encephalomyocarditis virus infection. J Virol. 1998;72:2752-9.

83. Player MR, Torrence PF. The 2-5A system: modulation of viral and cellular processes through acceleration of RNA degradation. Pharmacol Therapeut. 1998;78:55-113.

84. Garcia MA, Gil J, Ventoso I, Guerra S, Domingo E, Rivas C, Esteban M. Impact of protein kinase PKR in cell biology: from antiviral to antiproliferative action. Microbiol Mol Biol R. 2006;70:1032-60.

85. Stark GR, Kerr IM, Williams BRG, Silverman RH, Schreiber RD. How cells respond to interferons. Annu Rev Biochem. 1998:67:227-64.

86. Mossman $\mathrm{KL}$, Ashkar AA. Herpesviruses and the innate immune response. Viral Immunol. 2005:18:267-81.

87. Hwang SM, Kim KS, Flano E, Wu TT, Tong LM, Park AN, Song MJ, Sanchez DJ, O'Connell RM, Cheng GH, et al. Conserved herpesviral kinase promotes viral persistence by inhibiting the IRF-3-mediated type I interferon response. Cell Host Microbe. 2009:5:166-78.

88. Cordero H, Cuesta A, Meseguer J, Esteban MA. Characterization of the gilthead seabream (Sparus aurata L.) immune response under a natural lymphocystis disease virus outbreak. J Fish Dis. 2016;39:1467-76.

89. Flajnik MF. A cold-blooded view of adaptive immunity. Nat Rev Immunol. 2018;18:438-53.

90. Morales Poole JR, Paganini J, Pontarotti P. Convergent evolution of the adaptive immune response in jawed vertebrates and cyclostomes: an evolutionary biology approach based study. Dev Comp Immunol. 2017;75:120-6.

91. Burton DR. Antibodies, viruses and vaccines. Nat Rev Immunol. 2002;2:706-13.

92. Xu LJ, Podok P, Xie J, Lu LQ. Comparative analysis of differential gene expression in kidney tissues of moribund and surviving crucian carp (Carassius auratus gibelio) in response to cyprinid herpesvirus 2 infection. Arch Virol. 2014;159:1961-74.

93. Grabherr MG, Haas BJ, Yassour M, Levin JZ, Thompson DA, Amit I, Adiconis X, Fan L, Raychowdhury R, Zeng QD, et al. Full-length transcriptome assembly from RNA-Seq data without a reference genome. Nat Biotechnol. 2011:29:644-52.

94. Pertea G, Huang XQ, Liang F, Antonescu V, Sultana R, Karamycheva S, Lee Y, White J, Cheung F, Parvizi B, et al. TIGR gene indices clustering tools (TGICL): a software system for fast clustering of large EST datasets. Bioinformatics. 2003;19:651-2.

95. Conesa A, Gotz S, Garcia-Gomez JM, Terol J, Talon M, Robles M. Blast2GO: a universal tool for annotation, visualization and analysis in functional genomics research. Bioinformatics. 2005;21:3674-6.

96. Quevillon E, Silventoinen V, Pillai S, Harte N, Mulder N, Apweiler R, et al. InterProScan: protein domains identifier. Nucleic Acids Res. 2005;33: W116-W20

97. Langmead B, Salzberg SL. Fast gapped-read alignment with bowtie 2. Nat Methods. 2012;9:357-9.

98. Li B, Dewey CN. RSEM: accurate transcript quantification from RNA-Seq data with or without a reference genome. Bmc Bioinformatics. 2011;12:323.

99. Tarazona S, Garcia-Alcalde F, Dopazo J, Ferrer A Conesa A. Differential expression in RNA-seq: a matter of depth. Genome Res. 2011;21:2213-23. 
100. Bardou P, Mariette J, Escudie F, Djemiel C, Klopp C. jvenn: an interactive Venn diagram viewer. Bmc Bioinformatics. 2014;15:3419-20.

101. Langfelder $P$, Horvath S. WGCNA: an R package for weighted correlation network analysis. Bmc Bioinformatics. 2008;9:559.

102. Storey JD. A direct approach to false discovery rates. J Roy Stat Soc B. 2002; 64:479-98.

103. Lu WJ, Zhou L, Gao FX, Sun ZH, Li Z, Liu XC, Li SS, Wang Y, Gui JF.

Divergent expression patterns and function of two $C X C r 4$ paralogs in hermaphroditic Epinephelus coioides. Int J Mol Sc. 2018;19:2943.

Ready to submit your research? Choose BMC and benefit from:

- fast, convenient online submission

- thorough peer review by experienced researchers in your field

- rapid publication on acceptance

- support for research data, including large and complex data types

- gold Open Access which fosters wider collaboration and increased citations

- maximum visibility for your research: over $100 \mathrm{M}$ website views per year

At $\mathrm{BMC}$, research is always in progress.

Learn more biomedcentral.com/submissions 